Article

\title{
The Water Pollution Policy Regime Shift and Boundary Pollution: Evidence from the Change of Water Pollution Levels in China
}

\author{
Manhong Shen ${ }^{1,2}$ and Yongliang Yang ${ }^{1, *}$ \\ 1 School of Economics, Zhejiang University, Hangzhou 310027, China \\ 2 School of Business, Ningbo University, Ningbo 315211, China; smh@nbu.edu.cn \\ * Correspondence: yangyliang228@163.com; Tel.: +86-571-8684-3676
}

Received: 24 May 2017; Accepted: 13 August 2017; Published: 18 August 2017

\begin{abstract}
Boundary environmental pollution and pollution spillovers are important issues for improving the water quality of trans-boundary rivers. This paper explores the empirical effects of the evolution of the pollution reduction mandates on boundary pollution by studying the change of water pollution levels (as proxied by $\mathrm{pH}, \mathrm{BOD}, \mathrm{COD}$ and $\mathrm{NH} 3-\mathrm{N}$ ) of key state monitoring stations from 2004 to 2014. The empirical findings support the existence of boundary pollution and indicate the association between environmental policy and boundary pollution levels using propensity score matching, although the relation is conditional on which water pollution measure is considered. The pollution levels of monitoring stations on provincial borders are significantly higher than those of interior monitoring stations. The pollution of tributaries is more serious than that of the main stream, which was quickly reversed after the pollution reduction mandates changed. The improvement of the water environment showed great differences with the change of policy when we compare the water quality of monitoring stations in the upper reaches of provincial borders with the water quality downstream of provincial borders. Our empirical analysis finds strong evidence of strategic polluting across provincial borders. Local officials may manipulate pollution within their jurisdictions, and the overall pollution reduction target will exacerbate border pollution, whereas water quality inspection can reduce marginal pollution. Finally, we further validate the net impact of the policies on boundary pollution using a difference in difference (DID) approach.
\end{abstract}

Keywords: border effect; boundary pollution; propensity score matching; inter-jurisdictional externalities

\section{Introduction}

Pollution spillovers of trans-boundary rivers are one of the most important research questions in environmental economics because the negative externalities of pollution are amplified by the flow of water. The emissions from upstream exceed the capacity of the river to self-purify, which means that the downstream pollution levels are more serious than are the upstream levels. Rivers across jurisdictional boundaries are more polluted because of the decentralization of regional finance and environmental management, which leads to more serious boundary pollution phenomena. Sigman [1] found that the pollution upstream of jurisdictional boundaries will be $40 \%$ more serious when rivers cross national borders. The closer the border is, the more serious the pollution is. The harm of boundary pollution is very serious because it seriously damages the health of border residents [2], causing problems such as diarrheal diseases and digestive system cancers. The poor people who live on the border are disproportionately affected by boundary pollution. China is one of the countries with the lowest per capita freshwater resources, but its water quality has deteriorated over the past 30 years. Seventy-five percent of the nation's lake water cannot be used as drinking water [3], and half 
of all rivers are unsafe for human contact [4]. Ebenstein et al. [5] proved that the pollution has seriously hindered the improvement of health in China over the last two decades. The deterioration of water quality is an important cause of the high incidence of cancer in China [6]. The deterioration in water quality will increase the incidence of gastrointestinal cancer by 9.7\% [7]. Pollution crossing a river's jurisdictional boundaries can also cause environmental inequality, which has been particularly serious over the past few years [8]. More seriously, it affects the residents' environmental attitudes. He et al. [9] studied the impact of boundary water pollution on people's willingness to pay (WTP) and found that WTP is negatively affected by the water quality from the upstream. This phenomenon is more pronounced when the downstream has a weak negotiation capability. The system for controlling the quantity of pollutants, which environmental protection departments develop based on environmental carrying capacity, is weakened. This is a threat to ecosystem security.

Existing papers have examined the existence of boundary environmental pollution and pollution spillovers in China from different perspectives. Upstream regions locate polluting enterprises close to borders so that pollution is carried downstream. Cai et al. [10] studied industry-level activities along 24 major rivers in China and found that downstream areas of a province have $20 \%$ more pollutions. The enforcement of pollution reduction mandates is more lenient in the most downstream county of a province. As the boundary of the city, rural areas are often the focus of pollution emission. Wang et al. [4] found that water pollution in small rural firms is a growing problem throughout China. He et al. [11] found that the pollution from rural small and medium-sized chemical enterprises is very serious, using a case study in the Hebei province, because rural residents have no ability to exercise political power. The existence of boundary pollution has made the issue of local government governance more complex. There is also a branch of the existing literature whose findings are inconsistent with the above results. Yang and He [12] concluded that polluting enterprises do not choose to locate near jurisdictional borders because local governments tend to agglomerate their effects to boost economic growth.

Studies have found that institutional factors affect pollution abatement. A foundational model of Oates and Schwab [13] suggests that decentralization may increase inter-jurisdictional variation in pollution levels. Destructive regulatory competition, known as the "race to the bottom", indicates that decentralization may lower environmental quality. Fell and Kaffine [14] proved that the pollution levels of decentralization generally differ from that of a centralized planner's social welfare-maximizing problem if we permit capital retirement and abatement activities. Related empirical research has found strong evidence that the decentralization of environmental governance leads to more serious boundary pollution around the world. It is difficult to negotiate successfully between upstream and downstream, which leads to pollution occurring "not in my backyard". Sigman [15] studied the impact of decentralization on water quality by studying pollution in rivers around the world and found that federal countries exhibit greater inter-jurisdictional variation in pollution levels. Lipscomb and Mobarak [16] found an inverted U-shaped curve in the quality of river water crossing the border in Brazil. Trans-boundary environmental pollution may worsen under fiscal decentralization in developing countries with growth-driven governments. Greenstone and Jack [17] explored the puzzle of poor environmental quality and high health burdens in developing countries and concluded that political factors undermine efficient policymaking. Regional fiscal competition in China exacerbates the consequences of environmental decentralization. Local officials can manipulate the distribution of polluting activities through project permits and the implementation of pollution reduction mandates. Growth-driven provincial governments prefer to develop the economy, which leads to a race to the bottom in environmental pollution. Cat et al. [10] showed that the overall pollution reduction targets may increase the total emissions of pollution in China. Chinese local leaders' behavior is driven by a career incentive structure, and local leaders lessen the enforcement of environmental regulations to attract firms [18]. When environmental pollution became too severe to ignore, local officials began to control pollution under pressure to meet pollution reduction mandates. Zheng and Kahn [19] concluded that institutional factors affect the decisions of governments to tackle local pollution 
externalities in China by analyzing the current literature, as proved by Zheng and Shi [20] from the inter-country relocation of polluting industries.

Due to the deteriorating water quality, China's central government began to control the total amount of pollutants in major basins beginning in the 10th Five-Year Plan (10th FYP), but the river water quality has not improved significantly. The Five-Year Plans are the most important policy instruments in China. The central government has incorporated emissions reduction targets into the scope of official assessments from the 11th FYP, which led to a decline in pollutant emissions from various regions. One motivation for the Chinese Communist Party to eliminate pollution is to build legitimacy by signaling [21]. The problem is that border pollution disputes and environmental violence increased dramatically during this period. The first reason for this increase in violence may be that people's awareness of environmental protection has been gradually awakened with the improvement of living standards. However, the conflicts also indicate that environmental policy is not able to meet the needs of the public and may be ineffective. The formal implementation of water quality assessment was covered in the period of the 12th FYP; the emission reduction effect has still not been sufficiently studied. In view of the harm of boundary pollution, it is necessary to further study the effect of regulation on water quality improvement and boundary pollution. In particular, we must pay attention to the change of boundary pollution in the process of institutional evolution. China is in an economic transition period, and the tolerance for treating water pollution across the whole society is declining. Various pollution reduction mandates are being perfected to account for the public's environmental rights, environmental justice and general justice.

This paper examines the existence of boundary pollution as captured by the values of hydrogen ion concentration $(\mathrm{pH})$, dissolved oxygen (DO), chemical oxygen demand (COD) and ammoniacal nitrogen (NH3-N) using weekly water quality data from monitoring stations from 2004 to 2014 . We also investigate the effects and consequences of the 2006 and 2011 policy changes. Considering the heterogeneity of the monitoring stations, a propensity score-matching approach is used to mitigate selection based on unobservable variables. To confirm the net effect of the 2006 and 2011 policy changes from other factors, our identification strategy uses the difference in difference (DID) approach of constructing control groups by using internal monitoring stations. The pollution levels of monitoring stations on provincial borders are significantly higher than are those of interior monitoring stations, which varies greatly accompanied by policy changes. The water quality in the tributaries is better than that in the main streams before the water quality assessment, which reverses after the water quality assessment. The improvement of the water environment with the change of environmental policy showed great difference when we compare the water quality of monitoring site stations in the upper reaches of provincial borders with that downstream of provincial borders. The overall pollution reduction target aggravated border pollution, whereas water quality assessment eliminates boundary pollution. The conclusion of DID is consistent; the difference of policy effects is obvious. We confirmed the strategic behavior of local government in pollution reduction when studying only the four parameters, which may weaken the effectiveness an emission reduction policy.

This paper contributes to the existing research in three aspects. First, this paper uses weekly data on water quality from monitoring stations to study boundary pollution and the impact of environmental policy on boundary pollution in China. The existing studies have verified the existence of boundary pollution in China from the distribution of heavy industries, relocation of pollution companies and enforcement of environmental regulation. This article contributes to boundary environmental pollution and pollution spillover-related research in China. Second, unlike the existing papers, this paper finds significant differences between the impact of overall pollution reduction targets and water quality assessments on water quality by using a more rigorous approach. Little attention has been paid to the changes of boundary pollution accompanied by the strengthening in pollution reduction mandates. Further, existing studies often adopt pollutant emission intensity as a proxy for environmental regulation, which may be an endogenous variable. Our final contribution is to confirm 
strategic polluting by local officials' behavior in China. The existing studies may overestimate the efforts of local governments to reduce emissions.

The main objective of this paper is to examine the existence of boundary pollution in China and investigate the effects of the 2006 and 2011 policy changes. The remainder of this paper is organized as follows. Section 2 describes the institutional background and changes in China's water polluting regulations and hypothesis development. Section 3 describes the methodology used in the empirical analysis, including the specification of regression models. Section 4 provides the specification of variables, data source and descriptive statistics. Section 5 presents the empirical results and further discusses whether boundary pollution varies with environmental policies. Section 6 summarizes the findings of this paper.

\section{Evolution of China's Water Pollution Regulation and Hypothesis Development}

\subsection{Environmental Decentralization}

China first proposed the implementation of the control of total pollutants in the 10th FYP, released in 2001, which is also the first five-year plan for environmental protection, but the plan provides no specific measures and objectives. The 10th FYP clearly requires local governments to reduce pollutant emissions by $10 \%$ of the expected target. For many years, local officials in China have been motivated mainly by the promotion of GDP growth and tax revenue, so the main pressure facing local officials is economic development. An important reason for the rapid development of China's economy is the fast rise in the volume of foreign trade in industrial products, which has been accompanied by significant pollutant emissions. The regulatory agency of environmental protection is the Bureau of Environmental Protection (BEP). BEPs at each level are in charge of enforcing the environmental protection regulations in the localities, but local BEPs are controlled by local governments on the same level. The pollution reduction mandate is a typical localized pollution control that relies primarily on local environmental protection departments, which take orders from the local government. BEPs simply decomposed the targets of pollution reduction from higher levels and did not describe how local governments should meet these targets. Provincial governments allocate targets within their administrative boundaries and control the timing of regulations. Local officials also have flexibility over the spatial geography of heavy polluting industrial activities.

The emission reduction target of the 10th FYP was delineated with no coercive force, which allowed local officials to ignore environmental issues and devote their attention to economic development by promoting incentives. Local economic growth causes large amounts of pollutants, but local governments are reluctant to bear the costs of managing pollution because the cost of pollution control is high [22]. Due to the concealment of pollution emissions and the persistence of damage, the phenomenon of excessive pollution emissions exists across the country. Under the decentralization of government finance and environmental management, the total emissions of local pollutants may exceed expectations in some provinces because growth-driven governments chase GDP. Wu et al. [23] found that local officials use high-pollution technologies simply to achieve cost savings. Local governments lower environmental standards to compete for capital. Zhang [24] found that local MEPs are often encouraged by local government officials to turn a blind eye to environmental pollution.

The localization of environmental governance may create pollution spillovers in space, which will create boundary pollution. Local officials must minimize environmental emergencies and petitions which reduce the probability of their promotion, so local governments must still control the total amount of pollutant emissions. Local governments have an incentive to concentrate pollutant emissions downstream of the river, especially near a jurisdictional junction. In this way, the growth of GDP reflects the performance of local officials, whereas the social costs of pollution and the losses caused must be borne downstream. This has resulted in higher pollution in the border areas than in the region. Cai et al. [10] studied China's water pollution reduction policy from 1998 to 2008, which actually led to relaxed sewage charges levied in the downstream areas. Duvivier and Xiong [25] contrasted the 
polluting firms' location choices in Hebei province and found that polluting firms are more likely to establish themselves in provincial border counties than in interior ones, which they believe is the result of decentralization. The existence of trans-boundary pollution makes the border areas pollution paradise, which damages the whole community, especially the nearby residents [4]. Environmental regulation in China is the most complex and diverse in the world, but its implementation in rural areas is ineffective.

Hypothesis 1. Decentralization of fiscal and environmental management will form boundary pollution.

\subsection{Total Amount Control of Water Pollutants}

To achieve a gradual decrease in pollution, the central government set a binding target to reduce COD emissions by $10 \%$ for the first time in the period of the 11th FYP from 2006 to 2010. Zheng et al. [26] proved that the central government and the public put great pressure on local officials to mitigate pollution externalities from 2004 to 2009. Local governments were asked to reduce emissions to a level that was at least not below this target. The binding index has a legal effect, and the result is that it provides the reference for the promotion of local officials. The leading cadres of local government and state-owned enterprises, who may face punishment or dismissal if a target cannot be met, are responsible for the implementation in the "one vote veto" system. The Bureau of Environmental Protection (BEP) was promoted to the Ministry of Environmental Protection (MEP) in July 2008 to better protect the environment. Total pollutant discharge assessments have played a significant role in reducing local pollutant emissions. The scope of this environmental improvement may be limited because the higher authorities assess only COD.

To ensure the effectiveness of the binding targets, the central government signs responsibility contracts with local governments. Under the incentive for promotion, local officials will do their best to reduce water pollution emissions to hit targets. Zheng et al. [26] found that mayors have reduced the total amount of pollution emissions under pressure from the central government and the public during this period. Huang and Xia [27] proved that regional competition affected the intensity of environmental protection from 2002 to 2010 and that environmental regulation is the most effective measure in achieving pollution reduction. Binding targets may also cause strategic behavior in pollution reduction because only a few goals are examined. Kahn et al. [28] used a difference in difference to study water quality change in key river basins in China from 2004 to 2010 and found that COD emissions fell by $54 \%$, but other pollutants that were not included in the assessment content did not show a significant decline.

Although the assessment of pollutant discharge has improved the water quality, the effect on boundary pollution has not been completely positive. The pollution levels of rivers may occur in two opposing cases. The first case is that the boundary pollution will be reduced because the total amount of pollutant emissions will be reduced under the pressure of total pollutant discharge assessment due to increasing investment in pollution control. Under the same conditions of environmental carrying capacity and self-purification capacity, pollutants that flow downstream decrease, which may improve the overall basin water quality, accompanied by an improvement in boundary pollution. The opposing situation is that boundary pollution may be more serious, which implies that the pollution of the border area is higher than that of the internal area. Local governments want to achieve better emission reduction target at lower cost to minimize the impact on economic growth. To meet the higher levels of government assessment and public pressure, local officials may reduce the total emissions or just dump pollution downstream. Local governments may relax the regulations on polluting enterprises near jurisdictional boundaries and acquiesced in the pollution of jurisdictional boundaries with secret sewage. Cai et al. [10] used pollution source census data from China to study the behavior of wastewater pollution enterprises, which showed that $20 \%$ more polluting activities occur in the downstream county of a province. They also found that the enforcement of pollution fee collection 
is more lenient in the downstream of a province. Local environmental protection departments may also be more direct in transferring heavily polluting enterprises to the downstream areas. The central government has been changing promotion criteria for local officials, moving from purely output-based criteria to include more environmental goals, which affect relocation of polluting industries [20]. Wu et al. [29] found that new polluting firms choose to locate in westward provinces because of pollution reduction mandates in China from 2006 to 2010. The total amount of pollutants in the assessment is helpful for reducing the pollutant emission, but the phenomenon of boundary pollution has not been reduced and has even worsened in some areas. The assessment of the 11th FYP is mainly for the total COD emissions and emission reduction project progress and lacks specific requirements for water quality improvement. Local governments may only reduce total pollution emissions due to higher government assessment and public pressure and will discharge pollutants in the downstream areas to reduce the impact on economic development. It is an environmentally free ride. Polluting one's neighbor gives rise to destructive regulatory competition between jurisdictions.

Hypothesis 2. Pollutant emissions are reduced under total pollutant discharge assessment.

Hypothesis 3. The total amount of pollutant emissions assessment will exacerbate the phenomenon of boundary pollution.

\subsection{Total Amount Control of Water Pollutants and Water Quality Assessment}

People continue to complain about poor water quality and border pollution as Chinese incomes and the popularity of the network increase. Aware of the boundary pollution problem, the 12th FYP requires local governments to reduce COD emissions by $8 \%$ and ammonia emissions by $10 \%$ from 2011 to 2015, which is more stringent and a wider range compared to the 11th FYP. The main task of the water quality assessment system is to check the water quality of the monitoring stations that are directly managed by the central environmental protection department. Thirty percent of the monitoring points are near the provincial jurisdictional boundaries. A water quality assessment system first appeared in the river basin pollution control plan in 2006, although it was marked by weak enforcement. Six ministries jointly formulated and issued the specific assessment approach in April 2009, which did not form a rigid constraint until the first assessment came out in June 2011. Failures to meet water quality targets have affected the promotion of local officials since then [30].

The control of the total amount of water pollutants and the assessment of water quality did improve water quality in the 12th FYP relative to the 11th FYP because local officials were subject to higher targets and promotion incentives as discussed above. Water quality assessment may have brought about a decrease in the degree of boundary pollution. The strengthening of the total pollutant emission reduction system required local governments to reduce their total emissions of pollutants, while water quality assessment forced the cost of local pollution emissions to be internalized. Zheng and Shi [20] found that the pollution fee policy encourages relocation of polluting industries. Water quality assessment as a rigid constraint not only prompted local governments to focus on improving the domestic water quality but may also weaken the cross-border river boundary pollution phenomenon. Governments at all levels should seriously reduce pollution emissions and increase the input of pollutant treatment, which will undoubtedly improve water quality throughout the region.

Another situation under the river basin water quality assessment is that the water quality assessment may lead to strategic polluting for local government speculation. Water quality monitoring data may have been improved for inspection, but, in fact, the boundary pollution is scarcely reduced. Water quality assessment stipulates that the exit water quality must be higher than the entry water quality for a region if the goal of improving water quality cannot be met. Those upstream may discharge sewage behind the monitoring stations near the border, so that the water quality of the stations is normal, even though the upstream excessively discharges pollutants. Kahn et al. [28] proved 
that the water quality in the border areas is improving faster and that the newly built heavy polluting enterprises are less likely to choose the border area in this period. Downstream may discharge sewage before the monitoring stations near the border, so the water quality of the stations is poor, even though the upstream does not excessively discharge pollutants. Local officials are now willing to discharge pollutants in rural areas and tributaries of rivers to achieve their targets because these places lack supervision. Rural areas around the cities may absorb the spatial spillover of the industrial pollutant emissions from cities, which forms a kind of internal pollution paradise [31]. The local government may condone strategic polluting under pressure to meet pollution reduction mandates, especially the pressure to implement water quality assessment.

Hypothesis 4. The implementation of water quality assessment will reduce the observed boundary pollution.

Hypothesis 5. Local governments may engage in strategic polluting in pollution reduction in the context of decentralization.

\section{Empirical Strategy}

\subsection{Boundary Pollution Dynamics}

Water quality here is represented by $\mathrm{NpH}, \mathrm{DO}, \mathrm{COD}$ and NH3-N. NpH stands for the absolute value of the difference between the $\mathrm{pH}$ and 7 . Boundary is an indicator variable that takes a value of 1 if the monitoring station is in the nearby provincial boundary, and 0 otherwise. We expect to see rising levels of pollution in the boundary of a province as a result of the provincial governments' optimal responses to the pollution reduction mandates. $X$ represents control variables. We control for a range of socioeconomic, water resource, environment, demographic, seasonal effect and other characteristics to mitigate selection based on unobservable variables. The degree of regional economic development determines its industrial structure. There is a close relationship between per capita income and pollution emission according to the environmental Kuznets curve. Industrial wastewater discharge is one of the main causes of water pollution and regional industrial structure determines the amount of sewage discharge. The degree of openness is closely related to the regional economic development model, and many studies have examined the existence of the pollution heaven hypothesis in China. The total amount of water resources will affect the industrial structure of the region. The amount of surface water resources has a decisive effect on the self-purification capacity of the water environment. The higher the intensity of environmental regulation is, the better the water quality improvement is. The inspectors in the environmental protection department are directly supervising corporate emissions and environmental improvements, the proportion of which may demonstrate environmental enforcement efforts. River water flow changes vary widely in different months, so it is necessary to control the seasonal factors. The definitions of all the variables are summarized in Table 2.

$$
\text { Water quality } y_{i t}=\alpha_{0}+\alpha_{1} \text { boundary }_{i t}+\sum \tau_{j} * X_{j i t}+\sum \beta_{\mathrm{j}} * \text { year }_{j}+\sum \gamma_{\mathrm{j}} * \text { month }_{j}+\varepsilon_{i}+\delta_{i t}
$$

We use ordinary least squares (OLS) to estimate Model (1). Although the monitoring stations are widely distributed, the amount is not large, and the comparability between stations is the key to drawing conclusions. We compare the mean between groups to test whether there is a significant difference between monitoring stations on provincial borders and interior monitoring stations. The first step of this research is to estimate the coefficient of the boundary in a full sample from which we can verify the existence of boundary pollution. If the coefficient is significantly positive (or negative) when water quality is $\mathrm{NpH}, \mathrm{COD}$ or NH3-N, the value of $\mathrm{NpH}, \mathrm{COD}$ and NH3-N (DO) in boundary monitoring station is higher (or lower). We can conclude that pollution is more serious in border areas in H1. We compare the coefficient at different times to study the change of boundary pollution with the 
evolution of policy in $\mathrm{H} 3$ and $\mathrm{H} 4$. Monitoring stations of the main stream are subject to more regulation in China because the monitoring stations were first placed in the main streams. To further verify previous hypotheses, we estimate Model (1) in the main stream and tributaries. Local governments may exhibit strategic behavior in pollution abatement, and we can test Hypothesis 5.

$$
\text { Water quality } i t=\alpha_{0}+\alpha_{1} \text { upstream }_{i t}+\sum \tau_{j} * X_{j i t}+\sum \beta_{\mathrm{j}} * \text { year }_{j}+\sum \gamma_{\mathrm{j}} * \operatorname{month}_{j}+\varepsilon_{i}+\delta_{i t}
$$

To compare the difference of water quality between upstream and downstream stations, we estimate Model (2) in the samples, which are all from boundary stations. Lipscomb and Mobarak used a similar method to obtain more accurate conclusions. Upstream is an indicator variable that takes a value of 1 if the monitoring station is in the upstream of a provincial boundary, and 0 otherwise. We are most interested in the variation of the coefficient of upstream $\alpha_{1}$ in Model (2). The water quality of upstream monitoring stations is better than that of the downstream stations if the coefficient of upstream is significantly negative (or positive) in $\mathrm{NpH}, \mathrm{COD}$ and $\mathrm{NH} 3-\mathrm{N}$ (DO). Local governments have no incentive to dump sewage in their own upstream if there is no water quality assessment. If Hypothesis 5 is established, local officials may do anything to satisfy assessment targets; however, the coefficient of the upstream may change significantly.

OLS estimates can overcome the defects of the inter-group $t$ test by considering other control variables, but the independent assumptions of the explanatory variables are often not satisfied. Randomization is difficult to meet, which will seriously affect the conclusions of policy evaluation and, in particular, needs more attention in the micro data [32,33]. The selection of monitoring stations was not random in this study, so OLS estimates may not be suitable in models (1) and (2). Propensity score matching (PSM) is more appropriate for our study, in which the explanatory variable is independent of the explanatory variable in the case where the negligible assumption holds. The validity of propensity score matching is based on the absence of missing important variables, which means considering all of the main factors that might affect the explanatory variables [32,34]. The massive amount of data and sufficient covariates in this study can meet these needs, so this paper uses PSM to estimate the average treatment effect (ATE) and the average treatment effect on the treated (ATT). Although many studies only report ATE, policy-makers may be more interested in ATT because it indicates the net effect. We apply the most commonly used logit method to estimate the score of monitoring stations. The matching method can be divided into K-nearest neighbor matching, caliper matching, spline matching and kernel matching. Which method is best has not yet been unanimously agreed upon, so it is generally believed that the most robust results of the different methods are the most credible. Fredriksson and Wollscheid [35] also use a propensity score estimation approach to study the outcomes of environmental decentralization. Monitoring stations on provincial borders can be inherently different from their interior counterparts, so we use the PSM identification strategy. We implement propensity score matching analysis using the package in Stata as developed by Leuven and Sianesi [36].

\subsection{Impact Evaluation of the Policies}

We have verified the existence of boundary pollution in Section 3.1 and now further investigate the effects and consequences of the 2006 and 2011 policy change. We take the difference in differences (DID) approach in Equations (3) and (4) to evaluate the impact of total pollutant control in the 11th FYP and water quality assessment in the 12th FYP. There are significant differences in the implementation of environmental policy between monitoring stations on provincial borders and interior monitoring stations. We construct control groups using internal monitoring stations. The 11th and 12th FYPs in models (3) and (4), respectively, are time dummy variables. If the coefficient of boundary is significantly positive (or negative) in $\mathrm{NpH}, \mathrm{COD}$ and NH3-N (DO), we can confirm the existence of boundary pollution in H1. If the coefficients of the 11th and 12th FYPs are significantly negative (or positive) 
in $\mathrm{NpH}, \mathrm{COD}$ and $\mathrm{NH} 3-\mathrm{N}$ (or DO), it can be concluded that the policies have improved the water quality. We are most interested in the coefficient of the cross term, because they can measure the net effect of the policies on the water quality of the boundary monitoring stations. We can further check hypotheses 3 and 4 from $\alpha_{3}$. The policies exacerbate boundary pollution if $\alpha_{3}$ is significantly positive (or negative) in Nph, COD and NH3-N (or DO). When we estimate Model (3), we remove samples after 2010 that may be affected by water quality assessment. Similarly, we remove the samples before 2006 to balance the sample in model (4).

$$
\begin{aligned}
& \text { Water quality } y_{i t}=\alpha_{0}+\alpha_{1} \text { boundary }_{i t}+\alpha_{2} 11 \text { th FYP } P_{t}+\alpha_{3} \text { boundary }_{i t} * 11 \text { th FYP } P_{t}+ \\
& \sum \tau_{j} * X_{j i t}+\sum \beta_{j} * \text { year }_{j}+\sum \gamma_{\mathrm{j}} * \text { month }_{j}+\varepsilon_{i}+\delta_{i t} \\
& \text { Water quality } y_{i t}=\alpha_{0}+\alpha_{1} \text { boundary }_{i t}+\alpha_{2} 12 \text { th FYP } P_{t}+\alpha_{3} \text { boundary }_{i t} * 12 \text { th FYP } P_{t}+ \\
& \sum \tau_{j} * X_{j i t}+\sum \beta_{j} * \text { year }_{j}+\sum \gamma_{j} * \text { month }_{j}+\varepsilon_{i}+\delta_{i t}
\end{aligned}
$$

\section{Data}

Water quality data come from weekly reports of automatic water quality monitoring stations from 2004 to 2014, which can be obtained from the Ministry of Environmental Protection's data center. The monitoring stations are located in the main stream of the important rivers, the entrance and river mouths of the important tributaries, the important lakes and reservoirs, the national border rivers and major water conservancy projects in China (Figure 1). The monitoring stations studied in this paper include all stations, considering the possible bias caused by the artificial selection of the sites. China's automatic water quality monitoring system is constantly improving with changes in the monitoring sites. There were 73 monitoring points at the beginning of 2004, which increased to 82 in the eighth week of 2005. Two stations were added in the forty-eighth week of 2006; the monitoring points reached 100 in the twenty-second week of 2007, 115 in the twenty-third week of 2011, 131 in the twenty-third week of 2012, and grew to 145 stations in the twenty-third week of 2014. The monitoring station adopts the method of continuous online monitoring, and the monitoring frequency is once every $4 \mathrm{~h}$. The monitoring data are transmitted to the provincial monitoring center and the China Environmental Monitoring Station at the same time. Monitoring station management and data release are the responsibility of the Ministry of Environmental Protection, which can avoid the problem of self-reporting to some degree. The authenticity of the monitoring data is essential, as has been emphasized by Bernauer and Kuhn [37]. Weekly reports provide a summary of the data for the week including 4 pollution indicators such as $\mathrm{pH}, \mathrm{DO}, \mathrm{COD}$ and NH3-N. Monitoring data may be missing due to power supply, flood, or disconnection, so the data set is unbalanced panel data. An overview of the water quality data is provided in Table 1 and Figure 2.

In Table 1, water pollution has improved from 2006 for COD, but we do not find this phenomenon in other indicators. All water pollution indicators begin to improve significantly after 2010. There is a significant difference in water quality between monitoring stations on provincial borders and interior monitoring stations, as shown in Figure 2. We construct a range of socioeconomic, water resources, environment, demographic, seasonal effect and other characteristics to mitigate selection based on unobservable variables. Specific indicators, data sources of characteristic variables and descriptive statistics are listed below as Tables 2 and 3. All monetary variables are deflated to 2005 yuan using provincial GDP deflators because some data were missing in 2004. The aggregate data are processed by natural logarithm, which is comparable to different dimensions. 


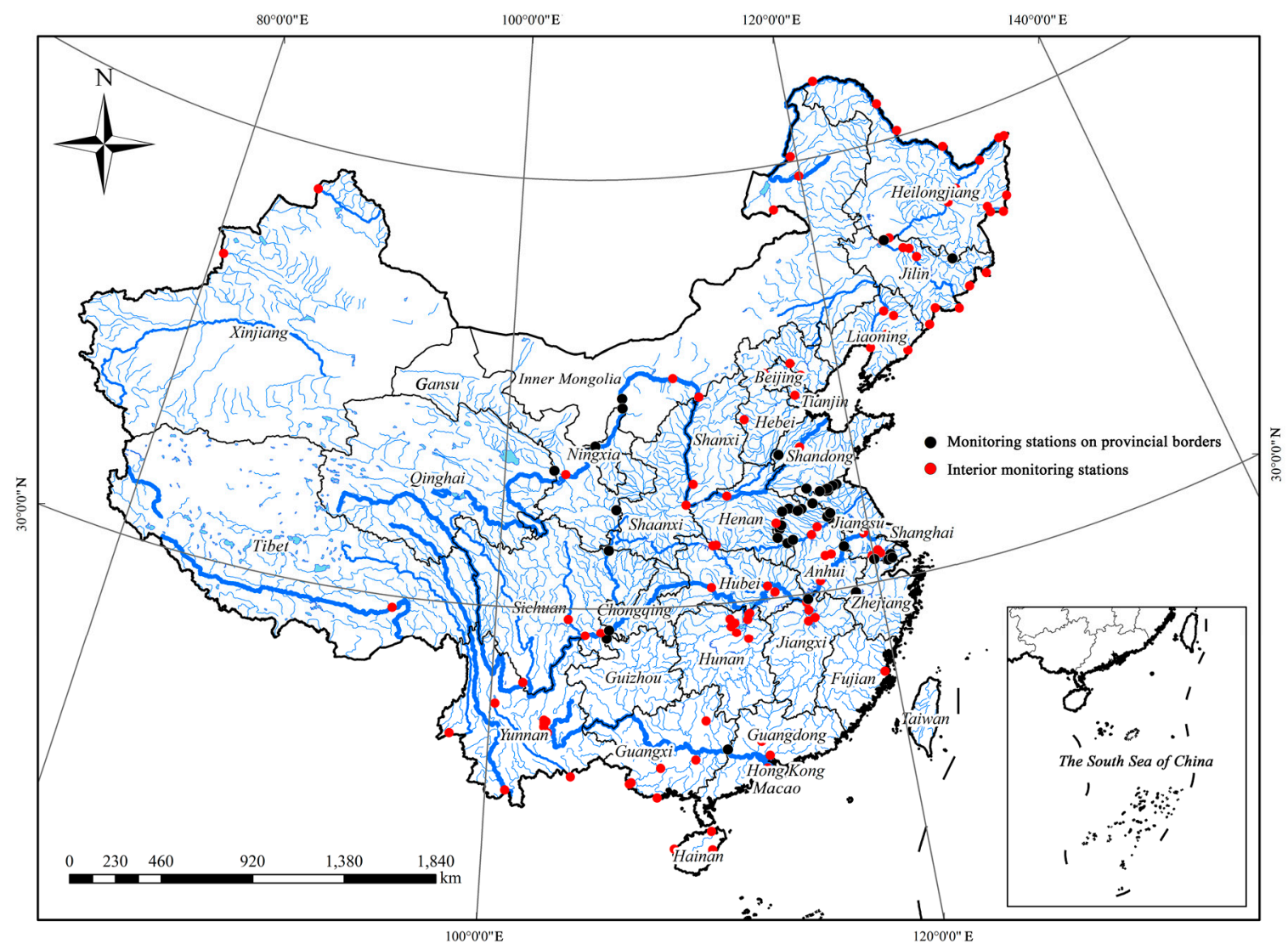

Figure 1. The spatial distribution of China's water quality monitoring stations.

Table 1. Water quality as tracked by monitoring stations.

\begin{tabular}{ccccccccc}
\hline \multirow{2}{*}{ Year } & \multicolumn{2}{c}{ pH } & \multicolumn{2}{c}{ DO (mg/L) } & \multicolumn{2}{c}{ COD (mg/L) } & \multicolumn{2}{c}{ NH3-N (mg/L) } \\
\cline { 2 - 8 } & Number & Mean & Number & Mean & Number & Mean & Number & Mean \\
\hline 2004 & 3397 & 7.682 & 3363 & 7.202 & 3397 & 5.672 & 3384 & 1.303 \\
2005 & 4072 & 7.672 & 4010 & 7.243 & 4060 & 5.840 & 4049 & 1.154 \\
2006 & 4121 & 7.664 & 4067 & 7.349 & 4116 & 5.753 & 4041 & 1.172 \\
2007 & 4789 & 7.723 & 4734 & 7.191 & 4766 & 5.864 & 4763 & 1.240 \\
2008 & 5015 & 7.791 & 4972 & 7.458 & 4961 & 5.682 & 5013 & 1.188 \\
2009 & 4926 & 7.758 & 4900 & 7.514 & 4914 & 4.856 & 4911 & 1.068 \\
2010 & 5048 & 7.745 & 5030 & 7.596 & 5045 & 4.758 & 5037 & 0.868 \\
2011 & 5576 & 7.811 & 5558 & 7.845 & 5567 & 4.600 & 5569 & 0.777 \\
2012 & 6272 & 7.703 & 6249 & 7.922 & 6263 & 4.113 & 6258 & 0.587 \\
2013 & 6641 & 7.660 & 6639 & 7.866 & 6630 & 4.097 & 6632 & 0.589 \\
2014 & 6855 & 7.673 & 6848 & 7.959 & 6857 & 4.09 & 6852 & 0.550 \\
\hline Total & 56,712 & 7.717 & 56,370 & 7.613 & 56,576 & 4.9 & 56,509 & 0.902 \\
Min & & 6.54 & & 0.53 & & 0.6 & & 0.02 \\
Max & & 8.98 & & 14.2 & & 44.5 & & 14.6 \\
\hline
\end{tabular}

Notes: Forty-eight of the 145 stations in 2014 are located in the mainstream, 65 are in the tributaries and the remainders are in lakes and other areas. There are 43 monitoring sites located near the provincial boundaries, including 21 upstream stations and 22 downstream stations. Values smaller than the 1st percentile are replaced by the values in the 1st percentile, and a similar procedure is used for the 95th percentile. Correlation matrix of control variables, median and standard deviation of water quality are available in Appendix A. 
Table 2. Covariant Form.

\begin{tabular}{|c|c|c|c|}
\hline Classification & Variable & Definition & Sources \\
\hline \multirow{2}{*}{$\begin{array}{l}\text { Regional economic } \\
\text { development }\end{array}$} & Pgdpc & $\begin{array}{l}\text { Natural logarithm of annual prefecture } \\
\text { level city per capita GDP }\end{array}$ & $\begin{array}{l}\text { Statistical yearbook of China's } \\
\text { regional economy }\end{array}$ \\
\hline & Pgdpp & $\begin{array}{l}\text { Natural logarithm of quarterly provincial } \\
\text { per capita GDP }\end{array}$ & $\begin{array}{l}\text { National Bureau of Statistics } \\
\text { website }\end{array}$ \\
\hline Industrial structure & Structure & $\begin{array}{l}\text { Annual city level industrial added value } \\
\text { accounted for the proportion of GDP }\end{array}$ & $\begin{array}{l}\text { Statistical yearbook of China's } \\
\text { regional economy }\end{array}$ \\
\hline \multirow{2}{*}{ Opening degree } & FDI & $\begin{array}{l}\text { Annual city level FDI accounted for the } \\
\text { proportion of GDP }\end{array}$ & $\begin{array}{l}\text { Statistical yearbook of China's } \\
\text { regional economy }\end{array}$ \\
\hline & Open & Monthly provincial export and import ratio & $\begin{array}{l}\text { National Bureau of Statistics } \\
\text { website }\end{array}$ \\
\hline \multirow{4}{*}{$\begin{array}{l}\text { Environment and } \\
\text { resource endowment }\end{array}$} & Pwater & $\begin{array}{l}\text { Natural logarithm of annual provincial per } \\
\text { capita water resources }\end{array}$ & \multirow{2}{*}{$\begin{array}{l}\text { China Environmental Statistics } \\
\text { Yearbook }\end{array}$} \\
\hline & Pswater & $\begin{array}{l}\text { Natural logarithm of annual provincial per } \\
\text { capita surface water }\end{array}$ & \\
\hline & Runoff & $\begin{array}{l}\text { Natural logarithm of mean annual runoff of } \\
\text { the river or lake }\end{array}$ & \multirow[t]{2}{*}{$\begin{array}{l}\text { China Water Resources } \\
\text { Statistical Yearbook }\end{array}$} \\
\hline & Length & Natural logarithm of river length & \\
\hline \multirow{5}{*}{$\begin{array}{l}\text { Environmental } \\
\text { protection }\end{array}$} & Fee & Natural logarithm of sewage charges & \multirow{5}{*}{$\begin{array}{l}\text { China Environmental Statistics } \\
\text { Yearbook }\end{array}$} \\
\hline & Intensity & Sewage charges per unit discharge & \\
\hline & Punishment & $\begin{array}{l}\text { Natural logarithm of the number of times } \\
\text { for environmental penalties }\end{array}$ & \\
\hline & Inspectionp & $\begin{array}{l}\text { The proportion of inspectors in provincial } \\
\text { environmental protection department }\end{array}$ & \\
\hline & Inspectionc & $\begin{array}{l}\text { The proportion of inspectors in county } \\
\text { environmental protection department }\end{array}$ & \\
\hline
\end{tabular}

Table 3. Descriptive Statistics.

\begin{tabular}{cccccc}
\hline Variable & Mean & S.D. & Median & Max & Min \\
\hline Pgdpp & 0.636 & 0.391 & 0.543 & 3.24 & 0.113 \\
Pgdpc & 9.985 & 0.739 & 9.952 & 11.81 & 8.226 \\
Structure & 0.419 & 0.126 & 0.419 & 0.836 & 0.001 \\
FDI & 31.513 & 29.115 & 19.671 & 178.76 & 0.004 \\
Open & 1.18 & 0.562 & 1.137 & 9.976 & 0.047 \\
Pwater & 6.942 & 1.012 & 7.086 & 9.661 & 4.288 \\
Pswater & 2.141 & 1.203 & 2.388 & 5.033 & -1.012 \\
Runoff & 6.744 & 1.451 & 6.442 & 9.135 & 4.836 \\
Length & 7.002 & 1.083 & 6.950 & 8.748 & 5.225 \\
Fee & 11.06 & 0.81 & 11.09 & 12.6 & 7.695 \\
Intensity & 0.363 & 0.288 & 0.304 & 2.824 & 0.023 \\
Punishment & 7.786 & 1.184 & 7.575 & 10.56 & 3.851 \\
Inspectionp & 0.402 & 0.163 & 0.386 & 0.966 & 0.000 \\
Inspectionc & 1.467 & 0.712 & 1.335 & 4.165 & 0.108 \\
\hline
\end{tabular}



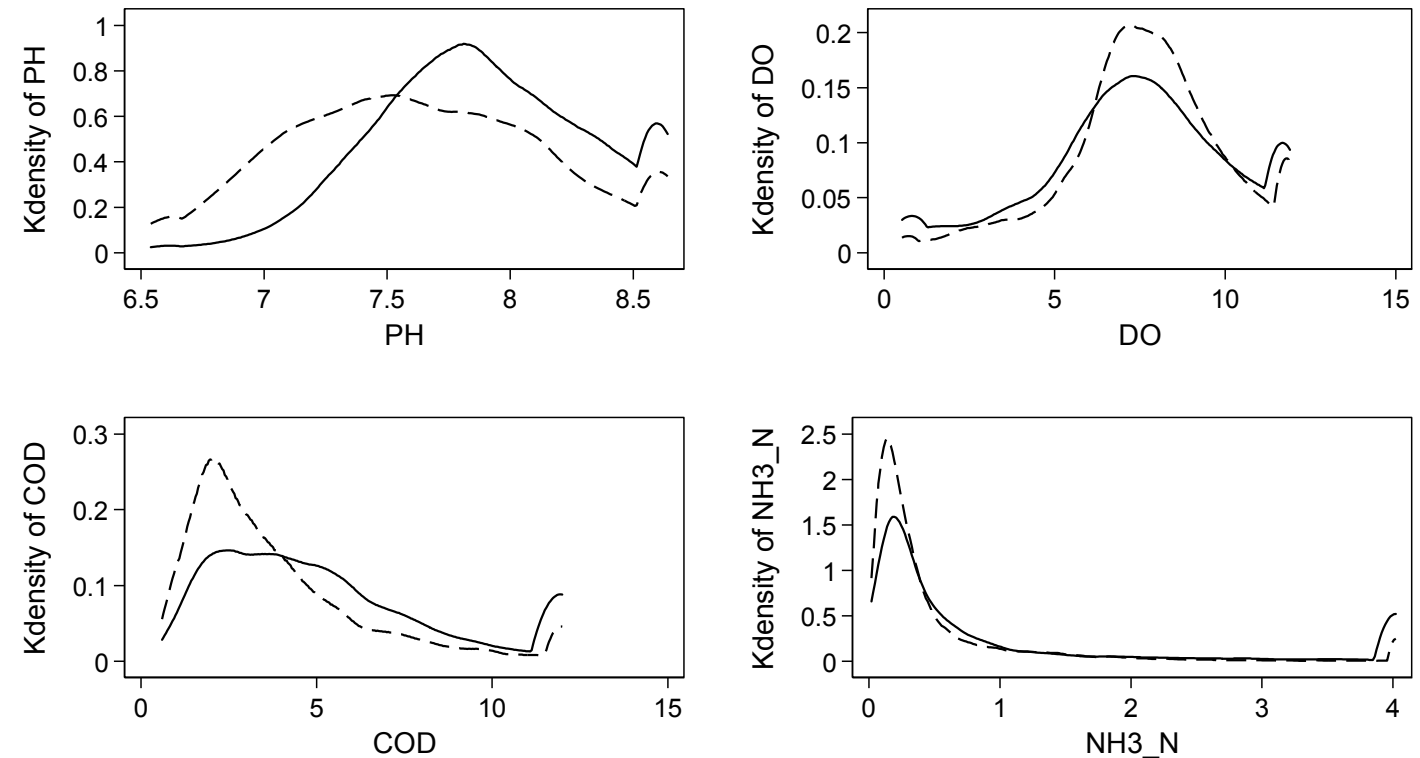

\section{- Water quality of monitoring stations on provincial borders - - - Water quality of interior monitoring stations}

Figure 2. Weekly average water quality.

\section{The Evolution of Boundary Pollution}

\subsection{The Existence of Boundary Pollution}

OLS is used to test the impact of monitoring stations near the provincial boundary on water quality, considering all of the control variables to control for confounding factors. The results of the inter-group difference test and OLS estimation for the presence of boundary pollution are shown in Table 4, from which we can find that the water quality of the monitoring stations on provincial borders is worse than that of interior monitoring stations. The deviation of the $\mathrm{pH}$ value from the normal value in the water of monitoring stations on provincial borders is greater than that of the interior monitoring stations, and the trend is increasing. The DO value in the water at the provincial boundary monitoring stations is lower than that of the interior monitoring stations overall, which has been strengthened by 2011 and will begin to weaken after 2011. The COD value of the water at the provincial monitoring stations is higher than that of the interior monitoring stations, but the difference in COD value is decreasing during the 11th Five-Year Plan and the 12th Five-Year Plan periods. The NH3-N value in the water at the provincial monitoring station is higher than that of the interior monitoring stations and the difference of NH3-N value is increasing before 2011 but decreasing during the 12th Five-Year Plan period.

Table 4. Boundary Pollution in ordinary least squares (OLS).

\begin{tabular}{ccccccccc}
\hline & \multicolumn{2}{c}{ NpH } & \multicolumn{2}{c}{ DO } & \multicolumn{2}{c}{ COD } & \multicolumn{2}{c}{ NH3-N } \\
\cline { 2 - 8 } & $t$ Tests & OLS & $t$ Tests & OLS & $t$ Tests & OLS & $t$ Tests & OLS \\
\hline Total sample & $0.26^{* * *}$ & $0.24^{* * *}$ & $-0.18^{* * *}$ & $-0.33^{* * *}$ & $2.82^{* * *}$ & $3.01^{* * *}$ & $1.04^{* * *}$ & $0.94^{* * *}$ \\
2004-2005 & $0.15^{* * *}$ & $0.09^{* * *}$ & $-0.22^{* * *}$ & $-0.48^{* * *}$ & $4.52^{* * *}$ & $3.92^{* * *}$ & $1.21^{* * *}$ & $0.90^{* * *}$ \\
$2006-2010$ & $0.25^{* * *}$ & $0.25^{* * *}$ & $-0.27^{* * *}$ & $-0.41^{* * *}$ & $3.40^{* * *}$ & $3.48^{* * *}$ & $1.33^{* * *}$ & $1.12^{* * *}$ \\
$2011-2014$ & $0.30^{* * *}$ & $0.24^{* * *}$ & $-0.12^{* * *}$ & $-0.22^{* * *}$ & $2.17^{* * *}$ & $2.18^{* * *}$ & $0.79^{* * *}$ & $0.71^{* * *}$ \\
\hline
\end{tabular}

Notes: 1 . To report as complete information as possible, this paper only reports the regression results of the dummy variables omitting the other control variables and the constant term; 2 . The $t$ test is a significant measure of the difference between monitoring stations on provincial borders and interior monitoring stations; $3{ }^{* * *}$ significant at 1 percent level. 
There are significant differences between monitoring stations on provincial borders and interior monitoring stations in nearly all of the indicators presented in Table 5. We therefore used PSM as a remedy, and the results are shown in Table 6. Here, we focus on ATE, with the ATT as reference. It can be found that the results of several matching methods are robust and the water quality of monitoring stations on provincial borders is significantly worse than that of interior monitoring stations. The deviation of the $\mathrm{pH}$ value from the normal value at monitoring stations on provincial borders is greater than that of interior monitoring stations. This phenomenon continues to deteriorate until the period of the 12th FYP. The COD value of the water at monitoring stations on provincial borders is higher than that of interior monitoring stations, and the gap is widening during the period of the 11th FYP but narrowing from the period of the 12th FYP. This phenomenon also exists in NH3-N: the pollutions near provincial boundaries first increase and then decrease. In addition to the DO values, these phenomena are consistent with those found in Table 4 . The DO value is an important index for measuring the self-purification capacity of the water body, and the increasing $\mathrm{DO}$ value indicates that the water body is in a state of continuous improvement.

Table 5. Differences between monitoring stations.

\begin{tabular}{ccccc}
\hline Variable & Boundary & Non-Boundary & Bias $\%$ & $t$ \\
\hline Pgdpp & 0.626 & 0.641 & -4 & $-4.06^{* * *}$ \\
Pgdpc & 9.660 & 10.139 & -68.8 & $-70.58^{* * *}$ \\
Structure & 0.405 & 0.426 & -17.2 & $-16.89^{* * *}$ \\
FDI & 25.366 & 34.244 & -32.3 & $-31.43^{* * *}$ \\
Open & 1.327 & 1.111 & 38.3 & $40.87^{* * *}$ \\
Pwater & 6.580 & 7.110 & -55.5 & $-56.67^{* * *}$ \\
Pswater & 1.737 & 2.329 & -51.9 & $-52.95^{* * *}$ \\
Fee & 11.335 & 10.930 & 51.9 & $53.85^{* * *}$ \\
Intensity & 0.402 & 0.345 & 19.6 & $21.03^{* * *}$ \\
Punishment & 7.698 & 7.827 & -11.1 & $-11.4^{* * *}$ \\
Inspectionp & 0.419 & 0.394 & 14.7 & $15.92^{* * *}$ \\
Inspectionc & 1.613 & 1.399 & 31.2 & $31.7^{* * *}$ \\
\hline
\end{tabular}

Although the $\mathrm{NpH}$ of the water has improved since 2011, the $\mathrm{NpH}$ value of the monitoring stations on provincial borders continues to deteriorate. $\mathrm{PH}$ is not included in the current pollutant emission reduction system and the binding to $\mathrm{PH}$ is weak in the cross-section assessment program. The $\mathrm{pH}$ value of water will improve due to the overall improvement of the water environment at the same time; for example, NH3-N itself is alkaline. According to the previous study, we can find that all indexes have boundary pollution in the period of the 10th FYP. During the period of the 11th FYP, the overall COD and NH3-N has been reduced under the pressure of total emissions reduction. The phenomenon of boundary pollution not only did not shrink, but it increased. It was not until the period of the 12th FYP that the phenomenon of boundary pollution was reduced under the dual pressure of total pollutant emission reduction and water quality assessment. Upstream agents concentrated water-polluting activities in the downstream to shift the burden of pollution to their downstream neighbors. This confirms the hypothesis above that total pollutant control can improve water quality but will bring boundary pollution, which requires water quality assessment system. We also perform the smoothness test after matching. Most of the variables were smaller in standard deviation between the control group and treated group, and most of the observed values were within the common range of the matching score, which proved that the results were stable after matching. 
Table 6. Propensity score matching results.

\begin{tabular}{|c|c|c|c|c|c|c|c|c|c|}
\hline & & \multicolumn{2}{|c|}{$\mathrm{NpH}$} & \multicolumn{2}{|c|}{ DO } & \multicolumn{2}{|c|}{ COD } & \multicolumn{2}{|c|}{ NH3-N } \\
\hline & & ATT & ATE & ATT & ATE & ATT & ATE & ATT & ATE \\
\hline (1) & $\begin{array}{l}\text { nearest neighbor } \\
\text { matching }\end{array}$ & $\begin{array}{l}0.22 * * * \\
(15.45)\end{array}$ & $\begin{array}{l}0.20^{* * *} \\
(15.07)\end{array}$ & $\begin{array}{l}0.09 \\
(1.02)\end{array}$ & $\begin{array}{l}-0.08 \\
(-1.13)\end{array}$ & $\begin{array}{l}3.57^{* * *} \\
(33.74)\end{array}$ & $\begin{array}{l}1.56^{* * *} \\
(14.66)\end{array}$ & $\begin{array}{l}0.77^{* * *} \\
(11.54)\end{array}$ & $\begin{array}{l}0.63^{* * *} \\
(14.67)\end{array}$ \\
\hline (2) & caliper matching & $\begin{array}{l}0.01 * * * \\
(19.24)\end{array}$ & $\begin{array}{l}0.21^{* * *} \\
(16.47)\end{array}$ & $\begin{array}{l}0.08^{*} \\
(1.82)\end{array}$ & $\begin{array}{c}0.03 \\
(0.63)\end{array}$ & $\begin{array}{l}3.59 * * * \\
(37.29)\end{array}$ & $\begin{array}{l}1.51^{* * *} \\
(15.02)\end{array}$ & $\begin{array}{l}0.78^{* * *} \\
(12.18)\end{array}$ & $\begin{array}{l}0.60^{* * * *} \\
(14.31)\end{array}$ \\
\hline (3) & spline matching & $\begin{array}{l}0.22^{* * * *} \\
(32.36)\end{array}$ & $\begin{array}{l}0.19^{* * *} \\
(35.02)\end{array}$ & $\begin{array}{l}0.02 \\
(0.5)\end{array}$ & $\begin{array}{c}0.03 \\
(0.98)\end{array}$ & $\begin{array}{c}3.80 * * * \\
(47.5)\end{array}$ & $\begin{array}{l}1.57^{* * *} \\
(25.25)\end{array}$ & $\begin{array}{l}0.87^{* * *} \\
(21.95)\end{array}$ & $\begin{array}{l}0.54^{* * * *} \\
(21.28)\end{array}$ \\
\hline (4) & kernel matching & $\begin{array}{l}0.22 * * * \\
(35.85) \\
\end{array}$ & $\begin{array}{l}0.17^{* * * *} \\
(39.96) \\
\end{array}$ & $\begin{array}{c}0.02 \\
(0.47) \\
\end{array}$ & $\begin{array}{c}0.03 \\
(0.97) \\
\end{array}$ & $\begin{array}{l}3.80^{* * *} \\
(48.05)\end{array}$ & $\begin{array}{l}1.61^{* * *} \\
(25.73)\end{array}$ & $\begin{array}{l}0.86^{* * *} \\
(19.61) \\
\end{array}$ & $\begin{array}{l}0.55^{* * *} \\
(22.22)\end{array}$ \\
\hline (5) & $\begin{array}{l}\text { nearest neighbor } \\
\text { matching with } \mathrm{AI}\end{array}$ & $\begin{array}{l}0.23^{* * *} \\
(39.94)\end{array}$ & $\begin{array}{l}0.21 * * * \\
(43.25)\end{array}$ & $\begin{array}{l}0.15^{* * *} \\
(5.02)\end{array}$ & $\begin{array}{l}0.06^{*} \\
(1.68)\end{array}$ & $\begin{array}{l}3.58^{* * *} \\
(88.21)\end{array}$ & $\begin{array}{l}1.47^{* * *} \\
(41.17)\end{array}$ & $\begin{array}{l}0.78^{* * *} \\
(36.18)\end{array}$ & $\begin{array}{l}0.59^{* * * *} \\
(42.53)\end{array}$ \\
\hline (6) & $\begin{array}{c}\text { Mahalanobis matching } \\
\text { with AI }\end{array}$ & $\begin{array}{l}0.21^{* * *} \\
(42.15)\end{array}$ & $\begin{array}{l}0.25^{* * *} \\
(68.64)\end{array}$ & $\begin{array}{l}-0.08^{* * *} \\
(-3.20)\end{array}$ & $\begin{array}{l}-0.02 \\
(-1.13)\end{array}$ & $\begin{array}{l}3.96^{* * *} \\
(130.09)\end{array}$ & $\begin{array}{l}2.06^{* * *} \\
(68.97)\end{array}$ & $\begin{array}{l}1.05^{* * *} \\
(70.59)\end{array}$ & $\begin{array}{l}0.75^{* * *} \\
(63.96)\end{array}$ \\
\hline (7) & 2004-2005 & $\begin{array}{l}0.10^{* * *} \\
(7.33)\end{array}$ & $\begin{array}{l}0.09 * * * \\
(5.05)\end{array}$ & $\begin{array}{c}0.08 \\
(1.34)\end{array}$ & $\begin{array}{l}0.24^{* * *} \\
(5.96)\end{array}$ & $\begin{array}{l}5.71^{* * *} \\
(48.62)\end{array}$ & $\begin{array}{l}1.92^{* * *} \\
(18.01)\end{array}$ & $\begin{array}{l}1.00^{* * *} \\
(22.28)\end{array}$ & $\begin{array}{l}0.37^{* * * *} \\
(12.29)\end{array}$ \\
\hline (8) & 2006-2010 & $\begin{array}{l}0.25^{* * *} \\
(31.02)\end{array}$ & $\begin{array}{c}0.21^{* * *} \\
(30.7)\end{array}$ & $\begin{array}{c}0.15^{* * *} \\
(3.01)\end{array}$ & $\begin{array}{l}-0.08 * * * \\
(2.71)\end{array}$ & $\begin{array}{l}6.10^{* * *} \\
(61.97)\end{array}$ & $\begin{array}{l}2.18^{* * *} \\
(30.45)\end{array}$ & $\begin{array}{l}1.90^{* * *} \\
(27.11)\end{array}$ & $\begin{array}{l}0.83^{* * *} \\
(33.10)\end{array}$ \\
\hline (9) & 2011-2014 & $\begin{array}{l}0.18^{* * *} \\
(21.55)\end{array}$ & $\begin{array}{l}0.22^{* * *} \\
(28.26)\end{array}$ & $\begin{array}{c}-0.09 \\
(-1.24)\end{array}$ & $\begin{array}{c}0.11^{* * *} \\
(3.05)\end{array}$ & $\begin{array}{l}2.40^{* * *} \\
(45.83)\end{array}$ & $\begin{array}{l}1.01^{* * *} \\
(18.98)\end{array}$ & $\begin{array}{l}0.61^{* * *} \\
(20.63)\end{array}$ & $\begin{array}{c}0.50^{* * * *} \\
(24.1)\end{array}$ \\
\hline
\end{tabular}

Notes: 1 . The first row is the first-order nearest neighbor, and we choose the fourth-order caliper matching for Row (2); 2. Nearest neighbor matching with AI chooses the four-nearest neighbor matching. 3; Rows (1-4) use bootstrap, and the following brackets are the $Z$ values that are repeated 300 times because of the method; 4 . Rows (5-9) use heteroskedasticity robust standard error, and the following brackets are the $t$ values. The results of the fourth-order nearest neighbor matching are considered the most robust by comparing different matching methods, so this method is used in the study for different time periods; $5 .{ }^{*}$ Significant at 10 percent level, ${ }^{* * *}$ significant at 1 percent level.

\subsection{Boundary Pollution in Main Streams and Tributaries}

There are significant differences in matching scores between monitoring stations in the main streams and tributaries in Figure 3. As shown in Table 7, there is a significant difference between the main stream and tributary in terms of border pollution. The four indicators all show that the monitoring stations at the tributaries are basically the same as the total samples, which means that the monitoring sites at the provincial boundaries are more polluted. The boundary pollution of tributaries is more obvious in some degree. The water quality of monitoring stations located at the main stream is quite different from the overall water quality. Although some indicators such as $\mathrm{NpH}$ and NH3-N support the existence of boundary pollution, the phenomenon weakens in both the economic and statistical sense. The water quality of monitoring stations on provincial borders in the main streams has higher DO and lower COD, which means that the water quality of monitoring stations on provincial borders is better. The reasons for the differences in the performance of the main streams and tributaries are multifaceted, but the following two factors may be most significant. First is an objective reason that the main stream flows from many tributaries and continues to have new tributary inflow, so the water self-purification ability is stronger. Second, the main stream is subject to more supervision. In the tributary control, however, pollution faces higher regulatory cost, which leads to polluting enterprises being concentrated in the tributaries. The monitoring stations are set up from the main stream out, which leads to the weak binding of the pollution control system to the grass roots government. However, the phenomenon is caused by the implementation of the pollution control system from top to bottom. The central government and the provincial government signed water environmental objective responsibility mandates, and the provincial and city governments signed them later. Local governments thus do not have an incentive to fully implement the current emission reduction policies, especially if they are also an important source of local revenue, because of the difficulty in transforming and upgrading sewage companies. Local governments must raise their pollution control funds, but the local government revenue sources are very limited. This verifies Hypothesis 5; i.e., that the implementation cost of water pollution control systems implemented 
from the top down is high and that local governments may focus on the detected values rather than actual emissions.

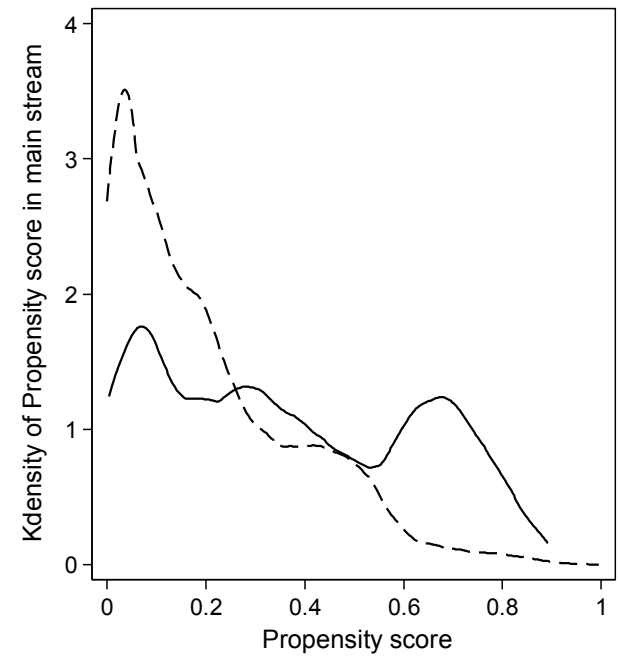

(a)

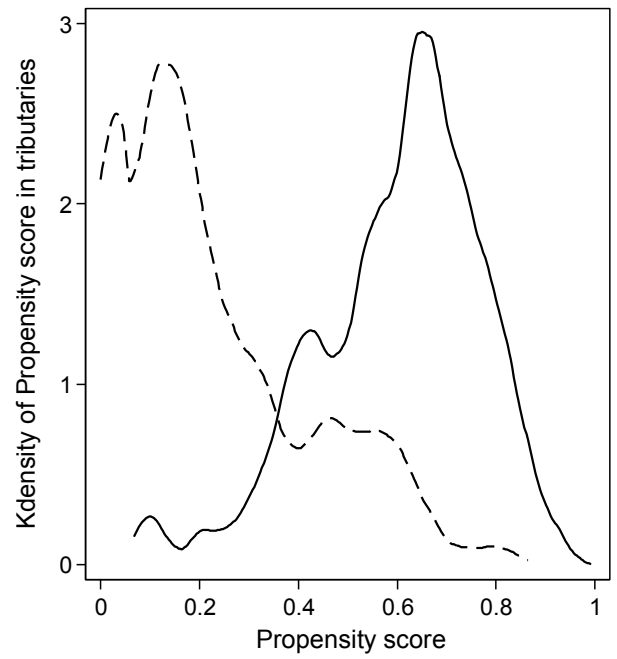

(b)

- Water quality of monitoring stations on provincial borders
-- Water quality of interior monitoring stations

Figure 3. Propensity score in main stream and tributary. Notes: (a) Propensity score of monitoring stations on provincial borders are significantly different with those of interior monitoring stations in main stream. (b) Propensity score of monitoring stations on provincial borders are significantly different with those of interior monitoring stations in tributaries. The distribution of propensity score of monitoring stations on provincial borders varies greatly in main stream and tributary when we compare (a) with (b).

Table 7. Differences of pollution levels between main stream and tributary.

\begin{tabular}{ccccccccc}
\hline & \multicolumn{2}{c}{ NpH } & \multicolumn{2}{c}{ DO } & \multicolumn{2}{c}{ COD } & \multicolumn{2}{c}{ NH3-N } \\
\cline { 2 - 9 } & $t$ Test & OLS & $t$ Test & OLS & $t$ Test & OLS & $t$ Test & OLS \\
\hline Main stream & $0.11^{* * *}$ & $0.10^{* * *}$ & $0.52^{* * *}$ & $0.45^{* * *}$ & $-1.33^{* * *}$ & $-0.79^{* * *}$ & $-0.13^{* * *}$ & $-0.11^{* * *}$ \\
Tributary & $0.40^{* * *}$ & $0.27^{* * *}$ & $-0.39^{* * *}$ & $-0.75^{* * *}$ & $5.35^{* * *}$ & $5.22^{* * *}$ & $1.60^{* * *}$ & $1.28^{* * *}$ \\
\hline & ATE & ATT & ATE & ATT & ATE & ATT & ATE & ATT \\
\hline \multirow{2}{*}{ Main stream } & $0.11^{* * *}$ & -0.01 & $0.25^{* * *}$ & $0.74^{* * *}$ & $-0.55^{* * *}$ & $-0.45^{* * *}$ & $0.03^{* * *}$ & $-0.12^{* * *}$ \\
& $(12.59)$ & $(-0.83)$ & $(7.11)$ & $(9.34)$ & $(-13.01)$ & $(-10.04)$ & $(2.86)$ & $(-8.14)$ \\
Tributary & $0.24^{* * *}$ & $0.24^{* * *}$ & $0.44^{* * *}$ & $0.44^{* * *}$ & $4.96^{* * *}$ & $4.96^{* * *}$ & $0.72^{* * *}$ & $0.72^{* * *}$ \\
& $(22.53)$ & $(22.53)$ & $(7.64)$ & $(7.64)$ & $(89.35)$ & $(89.35)$ & $(16.94)$ & $(16.94)$ \\
\hline
\end{tabular}

Notes: 1 . All results use fourth-order nearest neighbor matching and heteroskedasticity robust standard error, with the following brackets showing the $t$-values; 2 . All control variables and the constant term are included but not reported in OLS, the dummy variable of which is 1 if the monitoring station is on the tributary; $3 .{ }^{* * *}$ significant at 1 percent level. Differences of matching variables between monitoring stations in main stream and tributaries are available in Appendix B.

\subsection{The Changes of Pollution Levels between Upstream and Downstream}

According to the direction of the flow, monitoring stations on provincial borders can be divided into upstream and downstream stations across the provincial jurisdictional boundary. There are no monitoring stations across the two provinces at the same time. In this section, we use the objective provincial boundaries to divide the stations located near the provincial boundaries into two groups, which can help us avoid the irreversibility of monitoring stations from another perspective.

From the Figure 4 and ATE shown in Table 8, the difference between the upstream monitoring stations and the downstream monitoring stations is significant, and the upper monitoring stations have a better water environment overall. The relationship between the water quality upstream and 
downstream has changed dramatically over time. The DO value of the downstream stations is higher in the 10th and 11th FYPs, but this phenomenon was reversed during the period of the 12th FYP. The COD value of the downstream stations was significantly lower than that of the upstream stations in the 10th and 11th FYPs, but the value of the downstream stations was higher during the period of the 12th FYP. The NH3-N value of the downstream stations gradually worsened in contrast to that of upstream stations during the 10th and 11th FYPs but improved during the period of the 12th FYP. Similar trends can be found in OLS and difference tests as a reference. The water quality of upstream monitoring stations is worse than that of downstream monitoring stations, and this phenomenon is deteriorating in the 10th and 11th FYPs. The water quality of the downstream monitoring stations is worse than that measured by the upstream monitoring stations during the period of the 12th FYP.
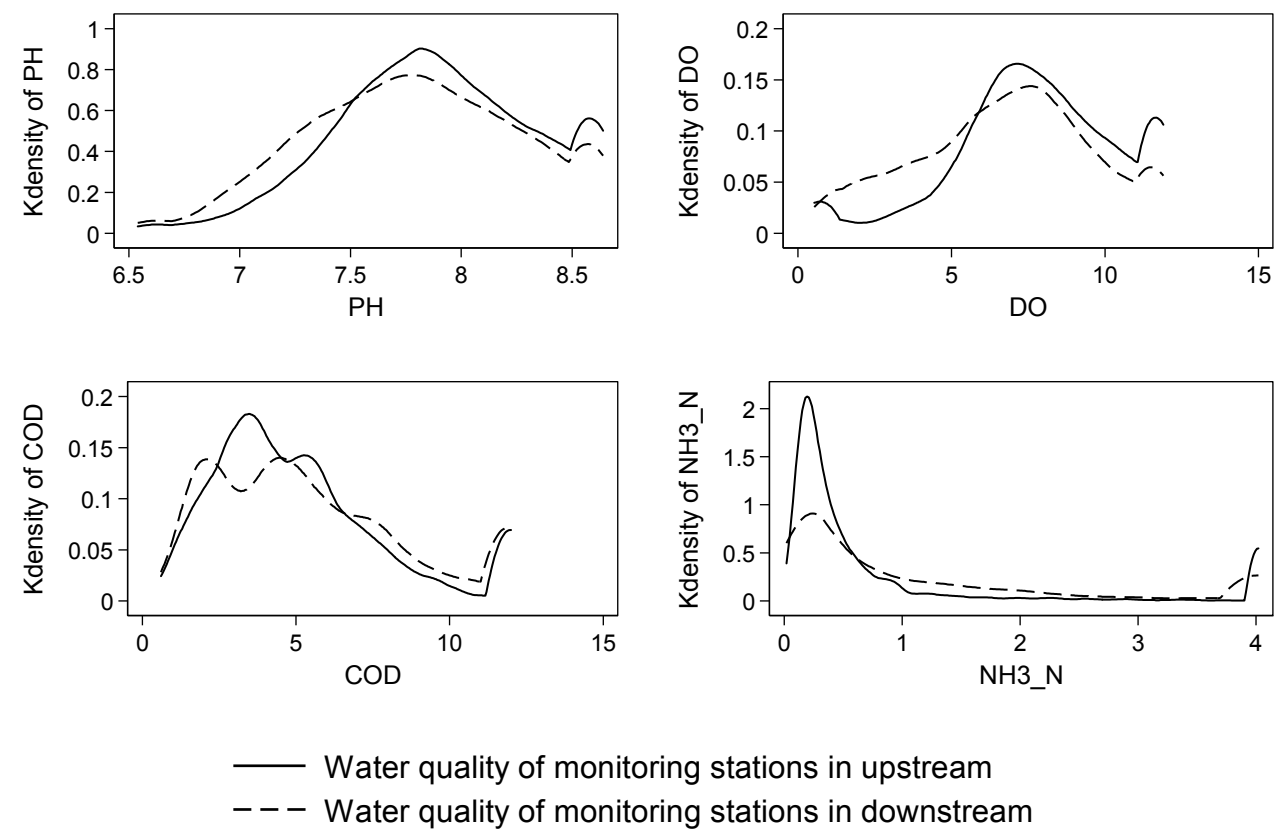

Figure 4. Differences of water quality in upstream and downstream.

Table 8. The changes of pollution levels between upstream and downstream.

\begin{tabular}{ccccccccc}
\hline & \multicolumn{2}{c}{ NpH } & \multicolumn{2}{c}{ DO } & \multicolumn{2}{c}{ COD } & \multicolumn{2}{c}{ NH3-N } \\
\cline { 2 - 9 } & $\boldsymbol{t}$ Test & OLS & $t$ Test & OLS & $t$ Test & OLS & $t$ Test & OLS \\
\hline Total sample & $-0.11^{* * *}$ & $-0.02^{* *}$ & $-1.04^{* * *}$ & $-1.53^{* * *}$ & $-0.56^{* * *}$ & $2.87^{* * *}$ & $0.27^{* * *}$ & $1.294^{* * *}$ \\
2004-2005 & $-0.27^{* * *}$ & $-0.25^{* * *}$ & $-0.41^{* * *}$ & $0.78^{* * *}$ & $-4.25^{* * *}$ & $-1.64^{* * *}$ & $-0.65^{* * *}$ & $-0.39^{* *}$ \\
$2006-2010$ & $-0.12^{* * *}$ & $-0.02^{*}$ & $-1.13^{* * *}$ & $1.97^{* * *}$ & $-2.88^{* * *}$ & $-1.88^{* * *}$ & $-0.25^{* * *}$ & $-1.63^{* * *}$ \\
$2011-2014$ & $-0.04^{* * *}$ & $-0.08^{* * *}$ & $-0.97^{* * *}$ & $-2.12^{* * *}$ & $0.60^{* * *}$ & $3.69^{* * *}$ & $0.43^{* * *}$ & $1.72^{* * *}$ \\
\hline & ATE & ATT & ATE & ATT & ATE & ATT & ATE & ATT \\
\hline \multirow{2}{*}{ Total sample } & $-0.11^{* * *}$ & $-0.22^{* * *}$ & $-2.04^{* * *}$ & $-1.33^{* * *}$ & $5.32^{* * *}$ & $1.79^{* * *}$ & $1.57^{* * * *}$ & $1.2^{* * *}$ \\
& $\left(^{*} 10.73\right)$ & $(-21.50)$ & $(-42.36)$ & $(-37.16)$ & $(18.33)$ & $(37.25)$ & $(31.93)$ & $(63.37)$ \\
$2004-2005$ & $-0.26^{* * *}$ & $-0.29^{* * *}$ & $0.19^{* *}$ & $0.6^{* * *}$ & $-2.49^{* * *}$ & $-3.98^{* * *}$ & -0.08 & -0.01 \\
& $(-11.68)$ & $(-10.11)$ & $(1.97)$ & $(5.31)$ & $(-7.8)$ & $(-10.45)$ & $(-0.77)$ & $(-0.1)$ \\
$2006-2010$ & $-0.16^{* * *}$ & $-0.30^{* * *}$ & $2.14^{* * *}$ & $1.79^{* * *}$ & $-3.75^{* * *}$ & $-1.72^{* * *}$ & $-1.99^{* * *}$ & $-1.47^{* * *}$ \\
& $\left(_{2}-16.86\right)$ & $(-24.47)$ & $(39.97)$ & $(31.19)$ & $(-31.62)$ & $(-25.04)$ & $(-24.22)$ & $(-55.34)$ \\
$2011-2014$ & $-0.08^{* * *}$ & $-0.19^{* * *}$ & $-2.65^{* * *}$ & $-2.29^{* * *}$ & $4.01^{* * *}$ & $3.22^{* * *}$ & $2.21^{* * *}$ & $2.09^{* * *}$ \\
& $(-7.85)$ & $(-16.33)$ & $(-28.47)$ & $(-17.17)$ & $(47.6)$ & $(22.66)$ & $(30.12)$ & $(42.94)$ \\
\hline
\end{tabular}

Notes: 1. All results use fourth-order nearest neighbor matching and heteroskedasticity robust standard error, with the following brackets showing the $t$-values; 2 . All control variables and the constant term are included but not reported in OLS, the dummy variable of which is 1 if the monitor station is on the upstream; $3 .{ }^{*}$ Significant at 10 percent level, ${ }^{* *}$ significant at 5 percent level, ${ }^{* * *}$ significant at 1 percent level. Differences of matching variables between monitoring stations in upstream and downstream are available in Appendix C. 


\subsection{The Impact of Policy Change on Water Quality}

To further confirm that changes in boundary pollution are the results of policy changes (Figure A1), we test the hypotheses taking a difference in difference approach. From the coefficient of boundary in Table 9, we believe that boundary pollution is always present. The coefficient of the 11th and 12th FYPs is significantly negative (or positive) in COD and NH3-N (DO), so the total amount of control of water pollutants and water quality assessment have improved the water quality. The coefficients of the cross term are significantly positive in $\mathrm{pH}$ and NH3-N in Rows (2) and (4) of Table 9, which means that the policy change from the 11th FYP exacerbated the boundary pollution. The impact of the policy change from 11th FYP is also reflected in the coefficient of COD, but the changes have improved the water quality from this perspective. Policy changes did not significantly affect the value of DO. Thus, the total amount of control of water pollutants exacerbates boundary pollution to some degree. The policy change beginning in the 12th FYP significantly improves water quality in all respects and, more clearly, in terms of COD relative to the 11th FYP. We can conclude that water quality assessment eliminates boundary pollution. We also adopt propensity score matching with difference-in-differences for robustness test, the results of which are available in Appendix D.

Table 9. The results of Difference-in-Difference for policy change.

\begin{tabular}{|c|c|c|c|c|c|c|c|c|}
\hline \multirow{2}{*}{ VARIABLES } & (1) & (2) & (3) & (4) & (5) & (6) & (7) & (8) \\
\hline & PH & DO & COD & NH3-N & PH & DO & COD & NH3-N \\
\hline \multirow{2}{*}{ Boundary } & $0.084^{* * *}$ & $-0.477^{* * *}$ & $4.219^{* * *}$ & $0.906^{* * *}$ & $0.274^{* * *}$ & -0.340 & $3.362^{* * *}$ & $1.157^{* * *}$ \\
\hline & $(6.535)$ & $(-5.855)$ & $(15.348)$ & $(10.714)$ & $(38.916)$ & $(-7.924)$ & $(30.273)$ & $(26.383)$ \\
\hline 11th FYP & $\begin{array}{c}0.106^{* * *} \\
(11.408)\end{array}$ & $\begin{array}{c}0.530 * * * \\
(10.909)\end{array}$ & $\begin{array}{c}-0.830^{* * *} \\
(-7.816)\end{array}$ & $\begin{array}{l}-0.414^{* * *} \\
(-11.805)\end{array}$ & & & & \\
\hline Boundary * 11th FYP & $\begin{array}{c}0.168^{* * *} \\
(11.145)\end{array}$ & $\begin{array}{c}0.036 \\
(0.389)\end{array}$ & $\begin{array}{c}-0.713^{* *} \\
(-2.296)\end{array}$ & $\begin{array}{c}0.246^{* *} \\
(2.502)\end{array}$ & & & & \\
\hline Boundary * 12th FYP & & & & & $\begin{array}{c}-0.047^{* * *} \\
(-4.571)\end{array}$ & $\begin{array}{c}0.150 * * \\
(2.481)\end{array}$ & $\begin{array}{c}-1.223^{* * *} \\
(-9.239)\end{array}$ & $\begin{array}{c}-0.586^{* * *} \\
(-10.968)\end{array}$ \\
\hline Observations & 24,398 & 24,142 & 24,300 & 24,244 & 39,544 & 39,313 & 39,426 & 39,386 \\
\hline Adj. R square & 0.201 & 0.0601 & 0.198 & 0.200 & 0.180 & 0.0411 & 0.186 & 0.172 \\
\hline
\end{tabular}

Notes: The $t$-value report is in the brackets below. ${ }^{*}$ Significant at 10 percent level, ${ }^{* *}$ significant at 5 percent level, *** significant at 1 percent level. Water quality varies at different times are available in Appendix D.

\section{Conclusions}

Using the PSM and DID identification strategy, this paper identifies the existence and dynamic change of boundary pollution with the water pollution policy regime shift in China, which provides strong evidence of strategic polluting by local officials. The pollutants studied are $\mathrm{pH}, \mathrm{BOD}, \mathrm{COD}$ and NH3-N, and we ascertain the existence of boundary pollution in China from the 10th FYP forward. Water quality has been improved under the total control of water pollutants, but border pollution is more serious under the 11th FYP. We believe that this is caused by the strategic polluting of local governments due to pressure from the central government and society. Water quality assessment forces local governments to work hard to improve water quality, especially the water quality of monitoring stations near provincial boundaries, and weaken the boundary pollution in the 12th FYP. The implication of the pollution reduction mandate since 2001 is twofold. The boundary pollution of the main stream is consistent with the whole basin, while tributaries are the opposite to some degree. This may be caused by objective reasons that the purification capacity of the main stream is stronger. Another possible reason for this phenomenon is the poor implementation of the government's emissions reduction policy. The implementation of pollutant emission control and water quality 
assessment was accompanied by a sharp change of water quality between upstream and downstream monitoring stations. Boundary pollution will increase with the total amount control of water pollutants and will be weakened with the water quality assessment system. Finally, this paper conditionally proves the influence of policy changes on the changes in boundary pollution. Due to data constraints, the proxy for water pollution levels only contains $\mathrm{pH}, \mathrm{BOD}, \mathrm{COD}$ and $\mathrm{NH} 3-\mathrm{N}$, and further research should be based on a wide range of parameters such as petroleum, mercury and phenol.

Acknowledgments: This work is supported by National Social Science Fund (14ZDA071). We are grateful to the experts of the International Symposium on Environmental Governance in China (PACE 2016) for helpful comments.

Author Contributions: Yongliang Yang had the original idea for the study. Manhong Shen help to conceive and design the research framework. Yongliang Yang analyzed the data and wrote the paper.

Conflicts of Interest: The authors declare no conflict of interest.

\section{Appendix A}

Table A1. Median and standard deviation of water quality.

\begin{tabular}{ccccccccc}
\hline \multirow{2}{*}{ Year } & \multicolumn{2}{c}{ PH } & \multicolumn{2}{c}{ DO } & \multicolumn{2}{c}{ COD } & \multicolumn{2}{c}{ NH3-N } \\
\cline { 2 - 9 } & P50 & SD & P50 & SD & P50 & SD & P50 & SD \\
\hline 2004 & 7.68 & 0.541 & 7.28 & 2.615 & 3.8 & 7.088 & 0.36 & 2.704 \\
2005 & 7.66 & 0.564 & 7.39 & 2.795 & 3.6 & 8.049 & 0.29 & 2.566 \\
2006 & 7.67 & 0.54 & 7.47 & 2.721 & 3.6 & 7.754 & 0.31 & 2.461 \\
2007 & 7.73 & 0.521 & 7.38 & 2.781 & 3.6 & 7.596 & 0.32 & 2.66 \\
2008 & 7.79 & 0.519 & 7.57 & 2.703 & 3.6 & 7.191 & 0.34 & 2.681 \\
2009 & 7.74 & 0.51 & 7.56 & 2.559 & 3.5 & 5.247 & 0.33 & 2.321 \\
2010 & 7.74 & 0.53 & 7.6 & 2.503 & 3.6 & 4.825 & 0.29 & 2.023 \\
2011 & 7.81 & 0.522 & 7.73 & 2.463 & 3.4 & 4.736 & 0.29 & 1.75 \\
2012 & 7.69 & 0.529 & 7.89 & 2.55 & 3.2 & 3.963 & 0.24 & 1.365 \\
2013 & 7.65 & 0.531 & 7.75 & 2.408 & 3.3 & 3.256 & 0.23 & 1.434 \\
2014 & 7.64 & 0.535 & 7.9 & 2.387 & 3.3 & 3.213 & 0.23 & 1.455 \\
Total & 7.71 & 0.533 & 7.64 & 2.587 & 3.4 & 5.732 & 0.28 & 2.12 \\
\hline
\end{tabular}

Table A2. Correlation matrix of control variables.

\begin{tabular}{|c|c|c|c|c|c|c|}
\hline & Pgdpc & Pgdpp & Structure & FDI & Open & Pwater \\
\hline Pgdpp & $0.598^{* * *}$ & 1 & & & & \\
\hline Structure & $0.019^{* * *}$ & $0.258^{* * *}$ & 1 & & & \\
\hline FDI & $0.302 * * *$ & $0.413^{* * *}$ & $0.193^{* * *}$ & 1 & & \\
\hline Open & $-0.066^{* * *}$ & $-0.048^{* * *}$ & $0.128^{* * *}$ & $0.133^{* * *}$ & 1 & \\
\hline Pwater & $-0.344^{* * *}$ & $-0.145^{* * *}$ & $-0.022 * * *$ & $-0.096^{* * *}$ & $-0.085^{* * *}$ & 1 \\
\hline Pswater & $-0.348^{* * *}$ & $-0.151^{* * *}$ & -0.006 & $-0.075^{* * *}$ & $-0.060 * * *$ & $0.992 * * *$ \\
\hline Fee & $0.202 * * *$ & $0.109 * * *$ & $0.366^{* * *}$ & $0.090 * * *$ & $0.226^{* * *}$ & $-0.160 * * *$ \\
\hline Intensity & $0.061^{* * *}$ & 0.004 & $0.121^{* * *}$ & $-0.090 * * *$ & $0.019^{* * *}$ & $-0.144^{* * *}$ \\
\hline Punishment & $0.288 * * *$ & $0.252 * * *$ & $0.234^{* * *}$ & $0.184^{* * *}$ & $0.158^{* * *}$ & $-0.150 * * *$ \\
\hline Inspectionp & $-0.014^{* * *}$ & $-0.068^{* * *}$ & $-0.129 * * *$ & $-0.050 * * *$ & 0.001 & 0.006 \\
\hline \multirow[t]{2}{*}{ Inspectionc } & $-0.089^{* * *}$ & $-0.212^{* * *}$ & $0.084^{* * *}$ & $-0.204^{* * *}$ & $-0.013^{* * *}$ & $-0.186^{* * *}$ \\
\hline & Pswater & Fee & Intensity & Punishment & Inspectionp & Inspectionc \\
\hline Pswater & 1 & & & & & \\
\hline Fee & $-0.148^{* * *}$ & 1 & & & & \\
\hline Intensity & $-0.165^{* * *}$ & $0.428 * * *$ & 1 & & & \\
\hline Punishment & $-0.157^{* * *}$ & $0.482^{* * *}$ & $0.020^{* * *}$ & 1 & & \\
\hline Inspectionp & $-0.020 * * *$ & $-0.150 * * *$ & $0.165^{* * *}$ & $-0.377^{* * *}$ & 1 & \\
\hline Inspectionc & $-0.160^{* * *}$ & $0.216^{* * *}$ & $0.157^{* * *}$ & $0.008^{*}$ & $-0.088^{* * *}$ & 1 \\
\hline
\end{tabular}

Notes: * Significant at 10 percent level, ${ }^{* * *}$ significant at 1 percent level. 


\section{Appendix B}

Table A3. Differences between monitoring stations in main stream and tributaries.

\begin{tabular}{ccccccc}
\hline \multirow{2}{*}{ Variable } & \multicolumn{3}{c}{ Main Stream } & \multicolumn{3}{c}{ Tributaries } \\
\cline { 2 - 7 } & Boundary & Non-Boundary & $\boldsymbol{t}$ Test & Boundary & Non-Boundary & $\boldsymbol{t}$ Test \\
\hline Pgdpp & 0.628 & 0.577 & $8.67^{* * *}$ & 0.629 & 0.711 & $-15.34^{* * *}$ \\
Pgdpc & 9.935 & 10.089 & $-11.99^{* * *}$ & 9.537 & 10.157 & $-72.16^{* * *}$ \\
Structure & 0.399 & 0.437 & $-13.88^{* * *}$ & 0.410 & 0.411 & -0.53 \\
FDI & 39.789 & 25.771 & $28.41^{* * *}$ & 20.154 & 38.762 & $-52.79^{* * *}$ \\
Open & 1.481 & 1.061 & $41.41^{* * *}$ & 1.274 & 1.109 & $24.38^{* * *}$ \\
Pwater & 6.786 & 7.164 & $-23.96^{* * *}$ & 6.420 & 7.103 & $-54.22^{* * *}$ \\
Pswater & 2.003 & 2.409 & $-22.91^{* * *}$ & 1.539 & 2.303 & $-49.02^{* * *}$ \\
Fee & 11.063 & 10.802 & 20.16 & 11.510 & 10.857 & $66.31^{* * *}$ \\
Intensity & 0.401 & 0.394 & $1.22^{* * *}$ & 0.397 & 0.284 & $33.74^{* * *}$ \\
Punishment & 7.553 & 7.681 & $-5.78^{* * *}$ & 7.840 & 7.905 & $-4.55^{* * *}$ \\
Inspectionp & 0.442 & 0.382 & $21.67^{* * *}$ & 0.405 & 0.408 & -1.29 \\
Inspectionc & 1.354 & 1.518 & $-14.07^{* * *}$ & 1.746 & 1.311 & $48.19^{* * *}$ \\
\hline
\end{tabular}

Notes: ${ }^{* * *}$ significant at 1 percent level.

\section{Appendix C}

Table A4. Differences between monitoring stations in upstream and downstream.

\begin{tabular}{ccccccc}
\hline \multirow{2}{*}{ Variable } & \multicolumn{3}{c}{ Upstream } & \multicolumn{3}{c}{ Downstream } \\
\cline { 2 - 7 } & Boundary & Non-Boundary & $\boldsymbol{t}$ Test & Boundary & Non-Boundary & $t$ Test \\
\hline Pgdpp & 0.579 & 0.965 & $-28.94^{* * *}$ & 0.674 & 1.174 & $-45.62^{* * *}$ \\
Pgdpc & 9.576 & 10.510 & $-40.59^{* * *}$ & 9.721 & 10.929 & $-58.29^{* * *}$ \\
Structure & 0.410 & 0.493 & $-24.41^{* * *}$ & 0.399 & 0.456 & $-18.01^{* * *}$ \\
FDI & 16.610 & 80.012 & $-106.13^{* * *}$ & 33.214 & 71.396 & $-49.75^{* * *}$ \\
Open & 1.368 & 2.215 & $-25.68^{* * *}$ & 1.285 & 1.778 & $-36.83^{* * *}$ \\
Pwater & 6.290 & 7.524 & $-29.37^{* * *}$ & 6.898 & 6.665 & $10.44^{* * *}$ \\
Pswater & 1.399 & 2.885 & $-30.65^{* * *}$ & 2.129 & 1.966 & $6.45^{* * *}$ \\
Fee & 11.286 & 11.524 & $-6.6^{* * *}$ & 11.371 & 11.100 & $13.55^{* * *}$ \\
Intensity & 0.451 & 0.285 & $9.35^{* * *}$ & 0.356 & 0.233 & $23.55^{* * *}$ \\
Punishment & 7.562 & 9.222 & $-33.83^{* * *}$ & 7.785 & 8.588 & $-26.03^{* * *}$ \\
Inspectionp & 0.429 & 0.347 & $11.35^{* * *}$ & 0.401 & 0.431 & $-5.8^{* * *}$ \\
Inspectionc & 1.810 & 1.150 & $19.34^{* * *}$ & 1.462 & 1.242 & $21.12^{* * *}$ \\
\hline
\end{tabular}

Notes: ${ }^{* * *}$ significant at 1 percent level. 


\section{Appendix D}
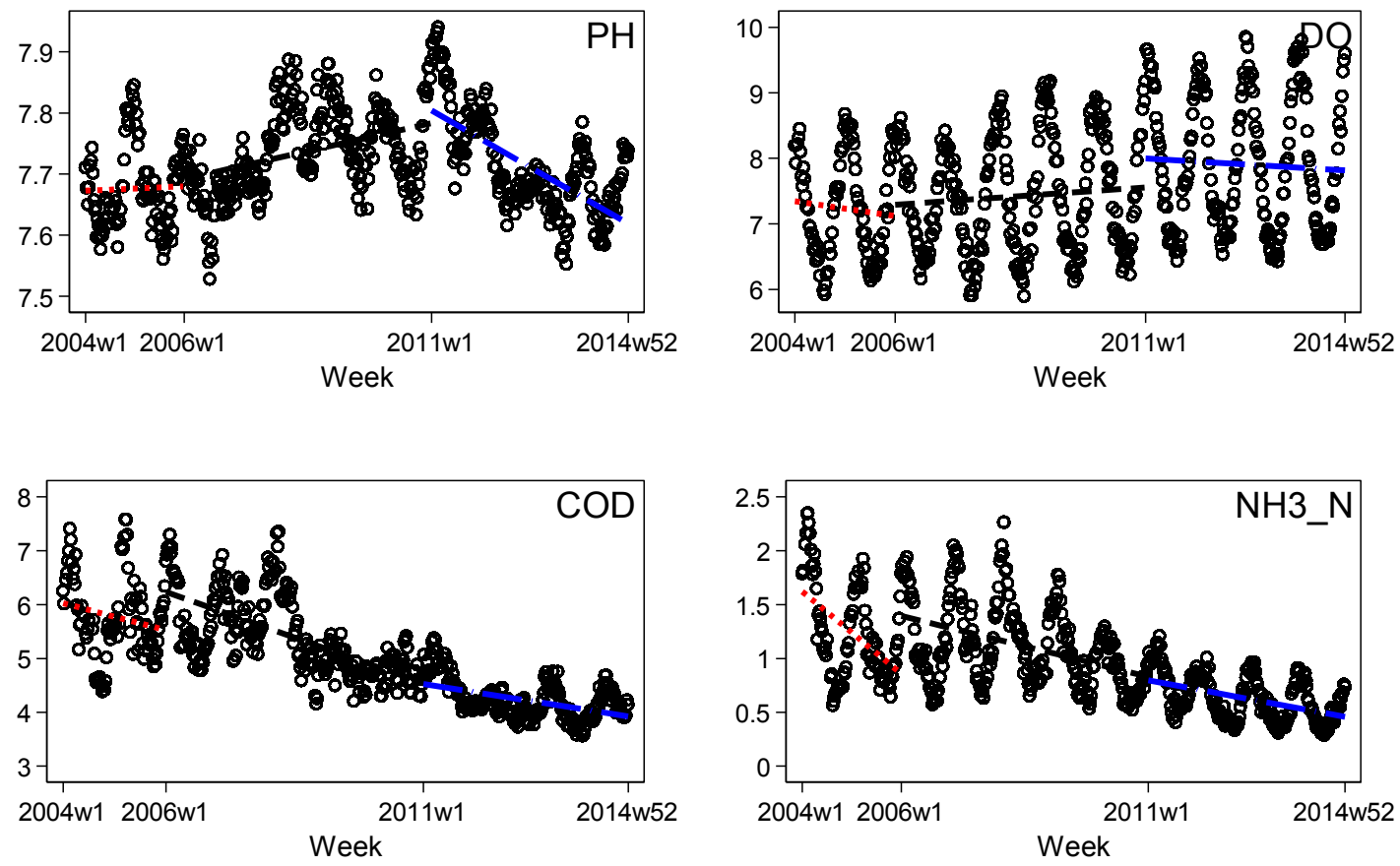

Figure A1. Water quality varies at different times.

Table A5. The results of Propensity score matching with difference-in-differences.

\begin{tabular}{|c|c|c|c|c|c|c|c|c|}
\hline VARIABLES & (1) & (2) & (3) & (4) & (5) & (6) & (7) & (8) \\
\hline & PH & DO & COD & NH3-N & PH & DO & COD & NH3-N \\
\hline boundary & $\begin{array}{c}0.138^{* * *} \\
(0.015)\end{array}$ & $\begin{array}{c}-0.261^{* * *} \\
(0.097)\end{array}$ & $\begin{array}{c}5.460^{* * *} \\
(0.301)\end{array}$ & $\begin{array}{c}1.014^{* * *} \\
(0.118)\end{array}$ & $\begin{array}{c}0.232 * * * \\
(0.009)\end{array}$ & $\begin{array}{c}0.359 * * * \\
(0.065)\end{array}$ & $\begin{array}{c}3.992^{* * *} \\
(0.125)\end{array}$ & $\begin{array}{c}0.758^{* * *} \\
(0.065)\end{array}$ \\
\hline 11th FYP & $\begin{array}{c}0.007 \\
(0.012) \\
\end{array}$ & $\begin{array}{c}0.181^{* * *} \\
(0.070)\end{array}$ & $\begin{array}{c}0.6611^{* * *} \\
(0.073)\end{array}$ & $\begin{array}{c}-0.418 \\
* * * \\
(0.074)\end{array}$ & & & & \\
\hline 12th FYP & & & & & $\begin{array}{c}0.020 \\
(0.013)\end{array}$ & $\begin{array}{c}1.076^{* * * *} \\
(0.082) \\
\end{array}$ & $\begin{array}{c}-0.751^{* * *} \\
(0.072) \\
\end{array}$ & $\begin{array}{c}-0.804^{* * *} \\
(0.054)\end{array}$ \\
\hline Boundary * 11th FYP & $\begin{array}{c}0.107^{* * *} \\
(0.017)\end{array}$ & $\begin{array}{l}-0.114 \\
(0.107)\end{array}$ & $\begin{array}{c}-1.874^{* * *} \\
(0.331)\end{array}$ & $\begin{array}{c}0.435^{* * *} \\
(0.128)\end{array}$ & & & & \\
\hline Boundary * 12th FYP & & & & & $\begin{array}{l}-0.008 \\
(0.016) \\
\end{array}$ & $\begin{array}{c}-0.436 \\
* * * \\
(0.097) \\
\end{array}$ & $\begin{array}{c}-1.462 * * * \\
(0.152) \\
\end{array}$ & $\begin{array}{l}-0.089 \\
(0.077) \\
\end{array}$ \\
\hline$x$ & Yes & Yes & Yes & Yes & Yes & Yes & Yes & Yes \\
\hline Constant & $\begin{array}{c}7.653^{* * *} \\
(0.011)\end{array}$ & $\begin{array}{c}7.317^{* * * *} \\
(0.066)\end{array}$ & $\begin{array}{c}3.739^{* * * *} \\
(0.061)\end{array}$ & $\begin{array}{c}1.127^{* * * *} \\
(0.072)\end{array}$ & $\begin{array}{c}7.688^{* * * *} \\
(0.008)\end{array}$ & $\begin{array}{c}6.860^{* * * *} \\
(0.054)\end{array}$ & $\begin{array}{c}3.933^{* * *} \\
(0.055)\end{array}$ & $\begin{array}{c}1.312 * * * \\
(0.048)\end{array}$ \\
\hline $\begin{array}{l}\text { Observations } \\
\text { Adj. R-squared }\end{array}$ & $\begin{array}{c}26,227 \\
0.050\end{array}$ & $\begin{array}{c}25,953 \\
0.003\end{array}$ & $\begin{array}{c}26,121 \\
0.036\end{array}$ & $\begin{array}{c}26,068 \\
0.066\end{array}$ & $\begin{array}{c}39,933 \\
0.062\end{array}$ & $\begin{array}{c}39,700 \\
0.026\end{array}$ & $\begin{array}{c}39,815 \\
0.086\end{array}$ & $\begin{array}{c}39,775 \\
0.042\end{array}$ \\
\hline
\end{tabular}

Notes: * Significant at 10 percent, ${ }^{* * *}$ significant at 1 percent. Robust standard error clustered at station is provided in brackets.

\section{References}

1. Sigman, H. International Spillovers and Water Quality in Rivers: Do Countries Free Ride? Am. Econ. Rev. 2002, 92, 1152-1159. [CrossRef]

2. Schwarzenbach, R.P.; Egli, T.; Hofstetter, T.B.; von Gunten, U.; Wehrli, B. Global water pollution and human health. Annu. Rev. Environ. Resour. 2010, 35, 109-136. [CrossRef] 
3. Ministry of Water Resources of the People's Republic of China, China Water Resources Bulletin 2015. Available online: http:/ /www.mwr.gov.cn/zwzc/hygb/szygb/qgszygb/201701/t20170119_785887.html (accessed on 19 January 2017).

4. Wang, M.; Webber, M.; Finlayson, B.; Barnett, J. Rural industries and water pollution in China. J. Environ. Manag. 2008, 86, 648-659. [CrossRef] [PubMed]

5. Ebenstein, A.; Fan, M.; Greenstone, M.; He, G.; Yin, P.; Zhou, M. Growth, pollution, and life expectancy: China from 1991-2012. Am. Econ. Rev. 2015, 105, 226-231. [CrossRef]

6. Chen, W.; Zheng, R.; Baade, P.D.; Zhang, S.; Zeng, H.; Bray, F.; Jemal, A.; Yu, X.Q.; He, J. Cancer statistics in China, 2015. CA Cancer J. Clin. 2016, 66, 115-132. [CrossRef] [PubMed]

7. Ebenstein, A. The consequences of industrialization: Evidence from water pollution and digestive cancers in China. Rev. Econ. Stat. 2012, 94, 186-201. [CrossRef]

8. Ma, C. Who bears the environmental burden in China-An analysis of the distribution of industrial pollution sources? Ecol. Econ. 2010, 69, 1869-1876. [CrossRef]

9. He, J.; Huang, A.; Xu, L. Spatial heterogeneity and transboundary pollution: A contingent valuation (CV) study on the Xijiang River drainage basin in south China. China Econ. Rev. 2015, 36, 101-130. [CrossRef]

10. Cai, H.; Chen, Y.; Gong, Q. Polluting thy neighbor: Unintended consequences of China's pollution reduction mandates. J. Environ. Econ. Manag. 2016, 76, 86-104. [CrossRef]

11. He, G.; Zhang, L.; Mol, A.P.; Wang, T.; Lu, Y. Why small and medium chemical companies continue to pose severe environmental risks in rural China. Environ. Pollut. 2014, 185, 158-167. [CrossRef] [PubMed]

12. Yang, X.; He, C. Do polluting plants locate in the borders of jurisdictions? Evidence from China. Habitat Int. 2015, 50, 140-148. [CrossRef]

13. Oates, W.E.; Schwab, R.M. Economic competition among jurisdictions: Efficiency enhancing or distortion inducing? J. Public Econ. 1988, 35, 333-354. [CrossRef]

14. Fell, H.; Kaffine, D.T. Can decentralized planning really achieve first-best in the presence of environmental spillovers? J. Environ. Econ. Manag. 2014, 68, 46-53. [CrossRef]

15. Sigman, H. Decentralization and Environmental Quality: An International Analysis of Water Pollution Levels and Variation. Land Econ. 2014, 90, 114-130. [CrossRef]

16. Lipscomb, M.; Mobarak, A.M. Decentralization and Pollution Spillovers: Evidence from the Re-drawing of County Borders in Brazil. Rev. Econ. Stud. 2017, 84, 464-502. [CrossRef]

17. Greenstone, M.; Jack, B.K. Envirodevonomics: A research agenda for an emerging field. J. Econ. Lit. 2015, 53, 5-42. [CrossRef]

18. Cao, X.; Kostka, G.; Xu, X. Environmental Political Business Cycles the Case of $\mathrm{PM}_{2.5}$ Air Pollution in Chinese Prefectures. Available online: http:/ / sites.psu.edu/xuncao/wp-content/uploads/sites/11338/2016/01/ Environmental_PBCs_april_2016.pdf (accessed on 20 April 2016).

19. Zheng, S.; Kahn, M.E. Understanding China's urban pollution dynamics. J. Econ. Lit. 2013, 51, 731-772. [CrossRef]

20. Zheng, D.; Shi, M. Multiple environmental policies and pollution haven hypothesis: Evidence from China's polluting industries. J. Clean. Prod. 2017, 141, 295-304. [CrossRef]

21. Wang, A. The Search for Sustainable Legitimacy: Environmental Law and Bureaucracy in China. Harv. Environ. Law Rev. 2013, 37, 336-439. [CrossRef]

22. Chang, H.F.; Sigman, H.; Traub, L.G. Endogenous decentralization in federal environmental policies. Int. Rev. Law Econ. 2014, 37, 39-50. [CrossRef]

23. Wu, D.; Xu, Y.; Zhang, S. Will joint regional air pollution control be more cost-effective? An empirical study of China's Beijing-Tianjin-Hebei region. J. Environ. Manag. 2015, 149, 27-36. [CrossRef] [PubMed]

24. Zhang, Z. Effective environmental protection in the context of government decentralization. Int. Econ. Econ. Policy 2012, 9, 53-82. [CrossRef]

25. Duvivier, C.; Xiong, H. Transboundary pollution in China: A study of polluting firms' location choices in Hebei province. Environ. Dev. Econ. 2013, 18, 459-483. [CrossRef]

26. Zheng, S.; Kahn, M.E.; Sun, W.; Luo, D. Incentives for China's urban mayors to mitigate pollution externalities: The role of the central government and public environmentalism. Reg. Sci. Urban Econ. 2014, 47, 61-71. [CrossRef]

27. Huang, J.; Xia, J. Regional Competition, Heterogeneous Factors and Pollution Intensity in China: A Spatial Econometric Analysis. Sustainability 2016, 8, 171. [CrossRef] 
28. Kahn, M.E.; Li, P.; Zhao, D. Water Pollution Progress at Borders: The Role of Changes in China's Political Promotion Incentives. Am. Econ. J. Econ. Policy 2015, 7, 223-242. [CrossRef]

29. Wu, H.; Guo, H.; Zhang, B.; Bu, M. Westward movement of new polluting firms in China: Pollution reduction mandates and location choice. J. Comp. Econ. 2017, 45, 119-138. [CrossRef]

30. Duan, W.; He, B.; Nover, D.; Yang, G.; Chen, W.; Meng, H.; Zou, S.; Liu, C. Water quality assessment and pollution source identification of the eastern Poyang Lake Basin using multivariate statistical methods. Sustainability 2016, 8, 133. [CrossRef]

31. Guo, J.; Xu, Y.; Pu, Z. Urbanization and Its Effects on Industrial Pollutant Emissions: An Empirical Study of a Chinese Case with the Spatial Panel Model. Sustainability 2016, 8, 812. [CrossRef]

32. Cameron, A.C.; Trivedi, P.K. Microeconometrics Using Stata; Stata Press: Bellingham, TX, USA, 2010.

33. Angrist, J.D. Mostly Harmless Econometrics: An Empiricist's Companion; Princeton University Press: Princeton, NJ, USA, 2010.

34. Imbens, G.W.; Wooldridge, J.M. Recent developments in the econometrics of program evaluation. J. Econ. Lit. 2009, 47, 5-86. [CrossRef]

35. Fredriksson, P.G.; Wollscheid, J.R. Environmental decentralization and political centralization. Ecol. Econ. 2014, 107, 402-410. [CrossRef]

36. Leuven, E.; Sianesi, B. PSMATCH2: Stata Module to Perform Full Mahalanobis and Propensity Score Matching, Common Support Graphing, and Covariate Imbalance Testing; Statistical Software Components: Boston, MA, USA, 2015.

37. Bernauer, T.; Kuhn, P.M. Is there an environmental version of the Kantian peace? Insights from water pollution in Europe. Eur. J. Int. Relat. 2010, 16, 77-102. [CrossRef]

(C) 2017 by the authors. Licensee MDPI, Basel, Switzerland. This article is an open access article distributed under the terms and conditions of the Creative Commons Attribution (CC BY) license (http:/ / creativecommons.org/licenses/by/4.0/). 